This is an Accepted Manuscript of an article published by Taylor \& Francis in Journal of Marketing Management on 6 Jan 2015, available

online: http://wwww.tandfonline.com/10.1080/0267257X.2014.995692 


\title{
THE ROLE OF PERCEIVED VALUE IN VERTICAL BRAND EXTENSIONS OF LUXURY AND PREMIUM BRANDS
}

\author{
Dr Francesca Dall’Olmo Riley ${ }^{\mathrm{a}^{*}}$ \\ ${ }^{a}$ Kingston University Business School \\ Kingston Hill \\ Kingston upon Thames KT2 7LB \\ UK \\ 02084175624 \\ f.d.riley@kingston.ac.uk \\ Dr José M. Pina ${ }^{\mathrm{b}}$ \\ jmpina@unizar.es \\ Dr Rafael Bravo \\ rbravo@unizar.es \\ ${ }^{\mathrm{b}}$ Universidad de Zaragoza \\ Gran Vía 2 \\ Zaragoza 50005 \\ Spain
}

Dr Francesca Dall'Olmo Riley

Dr Francesca Dall'Olmo Riley is Associate Professor in Marketing at Kingston University Business School, UK. Her research on branding and on online grocery shopping has been published in the International Journal of Research in Marketing, Journal of Business Research, Journal of Marketing Management, the European Journal of Marketing and other international journals.

\section{Dr José M. Pina}

Dr José M. Pina is Professor in Marketing at the University of Zaragoza (Spain). His research is focused on the study of brands, including corporate branding, online branding, luxury brands, brand extensions and brand alliances. He has published his research in the European Journal of Marketing, Journal of Business Research, Journal of Marketing Management, Service Industries Journal and other international journals.

\section{Dr Rafael Bravo}

Dr Rafael Bravo is Professor in Marketing at the University of Zaragoza (Spain). He researches brands and consumer behaviour. He has published his research in the Journal of Business Research, Service Industries Journal, Corporate Social Responsibility and Environmental Management and other international journals.

${ }^{*}$ Author for correspondence 


\title{
THE ROLE OF PERCEIVED VALUE IN VERTICAL BRAND EXTENSIONS OF LUXURY AND PREMIUM BRANDS
}

\begin{abstract}
This study examines the role of perceived value in the relationship between brand attitude, perceived fit, extension attitude and consumers’ purchase intention of downscale vertical extensions of luxury and premium brands in two product categories: cars and shoes. Results from 236 individuals with different income levels show that extension attitude is positively related to purchase intention both directly and indirectly, via the perceived value of the extension; the latter is more strongly correlated than extension attitude to consumers’ purchase intention. Brand attitude is also positively associated with perceived value. Overall, perceived value partially mediates the relationships of brand attitude and of extension attitude with purchase intention. The product category affects the strength of some of the relationships in the model, including the role of fit.
\end{abstract}

\section{Summary statement of contribution}

The study establishes the role of perceived extension value as a mediator of the relationships of brand attitude and of extension attitude with the purchase intention of vertical extensions of premium and luxury brands in two product categories. The product category affects some of the relationships in the model: the association between fit and perceived value is statistically significant only for the more conspicuous category of cars. No earlier study had undertaken such a comprehensive empirical analysis.

Keywords: Vertical brand extension; Luxury brand; Perceived value; Purchase intention; Mediating variable; SEM-PLS 


\section{Introduction}

For both fast moving consumer goods and luxury brands, extension is a popular growth strategy (e.g. Ambler \& Style, 1997; Albrecht, Backhaus, Gurzki, \& Woisetschläger, 2013). Managers can opt to extend a brand within its current product category through a 'line extension', or into a completely new product category with a ‘category extension’ (Aaker \& Keller, 1990). In practice, line extensions are much more frequent than category extensions (Les Echos, 2004); academic research, however, has focused mainly on category extensions (Grime, Diamantopoulos, \& Smith, 2002; Musante, 2007). This imbalance between line and category extension research may be explained, in part, by the fact that most researchers have been concerned with the level of fit between a brand and its extension from the point of view of product feature similarity. Since, by definition, line extensions have a strong degree of product feature similarities with their parent brands, researchers have not always recognised the need to investigate the effect of fit in this context (Grime et al., 2002).

In vertical line extensions, the brand is extended to a new product within the same category, but at a higher (upscale extension) or lower (downscale extension) price. In these instances, brand concept similarity may be an important dimension in the way consumers evaluate the fit between the vertical line extension and the parent brand. For example, in the case of a downscale vertical line extension, consumers may associate a lower price with lower quality, with ensuing negative impact on the value they attribute to the extension and on their intentions to purchase the new lower priced product (Liu \& Choi, 2009; Michel \& Salha, 2005).

Particularly in the case of brands which are positioned at the higher end of the price/quality, status and conspicuousness spectrum, understanding how consumers evaluate and value downscale vertical line extensions is not straightforward (Liu \& Choi, 2009). A number of 
simultaneous, complex and sometime opposing processes appear to be at play (Heath, DelVecchio \& McCarthy, 2011). Consumers may consider a lower priced line extension as inconsistent and incompatible with the dominant concept in their minds of luxury brands as status symbols (Desai \& Hoyer, 1993). Furthermore, a substantially lower price renders the brand accessible to a larger consumer segment, resulting in the massification or democratization of luxury (Michel \& Salha, 2005; Nueno \& Quelch, 1998). This increased availability is likely to lower the status evaluation of the luxury brand's downscale line extension (Kim, Lavack, \& Smith, 2001; Lei, de Ruyter \& Wetzels, 2008a). On the other hand, in the context of horizontal extensions, Liu and Choi (2009) suggest that consumers would take for granted the transfer of superior quality from luxury brands to their extensions. It is unclear whether this is the case also in the context of the downscale vertical line extension of a luxury brand and the extent to which consumers would evaluate the lower priced product positively, even if its increased affordability may lower its perceptions of exclusivity. As Heath et al. (2011: 19) point out, 'further research on' (downscale vertical line extensions of) 'luxury brands is needed, partly because regular luxury-brand consumers may not like seeing their brands being consumed by the masses (Berger \& Heath, 2007; Kirmani et al., 1999)’.

Further complexity is added by fact that, even at the upper end of the spectrum, brands vary on a continuum of prestige and price (De Barnier, Falcy, \& Valette-Florence , 2012; Reddy, Terblanche, Pitt, \& Parent, 2009; Truong, McColl, \& Kitchen, 2009), as well as status and conspicuousness (Truong, Simmons, McColl, \& Kitchen, 2008; Vigneron \& Johnson, 2004). In the context of vertical extensions, it is particularly important to acknowledge such variations in the continuum of prestige, price and exclusivity. For example, for luxury brands at the topmost end of the spectrum there is more room for downward positioning and less room for upscale 
extensions (a ceiling effect) than for premium brands which are lower down on the continuum. On the other hand, for premium brands there may be a floor effect, whereby there is less room for a downscale extension, because of the risk of devaluing the brand to the level of a functionoriented one. Hence, there may be potential differences between premium and luxury brands with regards to the value consumers attribute to vertical extensions and to their intention to purchase such extensions. Furthermore, consumers' evaluations of downscale vertical extensions may also vary depending upon the product category, for example whether car brands, which are very conspicuous and recognizable, or fashion brands are extended.

Investigating downscale vertical line extensions (from now on vertical extensions) and the role of the perceived value of such extensions under different conditions (e.g. premium v luxury brands) is the focus of our research. This is important for both practice and theory.

In practice, during the recent economic downturn, luxury brands such as Gucci, Cadillac or Porsche have frequently employed downscale vertical extensions in the attempt to boost sales, introducing products that would be perceived by consumers as good value for money and more accessible compared with similar products offered by themselves or by other luxury brands, but at the risk of pursuing short term profit at the expense of brand exclusivity (Bokaie, 2008; Buss, 2013).

In academic research, however, there is a dearth of studies considering the determinants of the perceived value and purchase intentions of vertical extensions, with the study by Lei et al. (2008a) in the context of services as a notable exception. Perceived value is commonly defined in the literature as "the trade-off between the expenses and sacrifices that consumers need to bear and the expected returns they are supposed to get" (Zeithaml, 1988, cited in Lei et al., 2008a). In the context of vertical extensions of luxury brands, the possible trade-off between the 
loss of exclusivity derived from a more affordable price and the value for money of the extension, compared with equivalent products from other luxury brands, is not well understood. In addition, contextual conditions such as the type of brand (luxury or premium), the product category and the price of the downscale extension may be important in affecting consumers' perceived value of vertical brand extensions. Yet, the influence of these contextual factors has been largely ignored in brand extension research.

In summary, the main objective of this study is to investigate brand attitude, perceived fit and extension attitude as antecedents of consumers' perceived value of downscale vertical extensions of luxury brands and the mediating role of the latter on consumers' intentions to purchase such extensions. We test the relationships between perceived extension value, purchase intention and their determinants first overall, then under different conditions, or control variables, namely the type of brand (luxury or premium), the product category (cars or fashion shoes) and the price of the downscale extension (in terms of discount size: $-25 \%$ vs. $-50 \%$ ).

In the following section, we summarise the literature and develop hypotheses regarding the relationships of brand attitude, extension attitude and fit to the perceived value of a downscale vertical extension, as well as the associations of perceived value and extension attitude with purchase intention. We then discuss brand/ product characteristics and extension characteristics (price) as control variables. First we test the proposed model overall, then we control for brand/ product characteristics and extension characteristics (price). The paper concludes with a discussion of the findings, managerial implications and suggestions for further research. 


\section{Background}

\section{Vertical extensions}

The literature on line extensions is considerably more limited than the literature on category extensions. By means of line extensions, companies resort to an established brand name to market new products in the same product category (Aaker \& Keller, 1990; Reddy, Holak, \& Bhat, 1994). Line extensions consist of either horizontal extensions or vertical extensions (Keller \& Aaker, 1992; Kim \& Lavack, 1996; Kirmani, Sood, \& Bridges, 1999). Horizontal extensions typically involve line stretching, with products that simply provide a new functional feature, whereas with vertical extensions the brand aspires to enter into a new market segment through upscale (also called upward or step-up) or downscale (downward or step-down) changes in price and positioning (Michel \& Salha, 2005). By means of upscale extensions, an improved version of the main product can target the premium sector of the market. On the other hand, downscale extensions often entail both a lower price and a lower quality level (Aaker, 1997; Kirmani et al., 1999; Liu, 2002).

Line extensions are not without risks. The risk of brand image dilution is especially strong for vertical extensions (Aaker, 1997; Michel \& Salha, 2005) and will occur when consumers find a dissonance between the quality of the parent brand and the quality of the extension (Kim et al., 2001). If the company opts for a downscale extension, the core brand could acquire low quality associations (Aaker, 1997; Randall, Ulrich, \& Reibstein, 1998) which can also tarnish the other products under the brand's umbrella (Michel \& Salha, 2005). A further risk of downscale vertical extension is the cannibalization of sales from higher priced products, particularly if the new product is too similar and not differentiated enough from the more expensive ones (Michel \& Salha, 2005). 
Regarding upscale extensions, Munthree, Bick and Abratt (2006) suggest that this strategy may help revitalise a brand, provided that the positioning and the credibility of the new product are adequate and the extension is neither first-to-market nor late-to-market. Although upscale extensions can build positive brand associations (Randall et al., 1998), consumers might be suspicious of formerly inexpensive brands that promise to deliver functional and emotional benefits in premium segments (Aaker, 1997; Speed, 1998). For example, perceptions of incompatibility and confusability might arise if a brand positioned at one end of the price or status continuum were to launch an extension at the other end of the continuum (e.g. an ‘economy’ car brand launching a ‘luxury’ car) (Desay \& Hoyer, 1993).

However, when comparing higher quality with lower quality vertical extensions, Heath et al. (2011) report a recurring asymmetry, whereby higher-quality extensions improve overall brand perception and evaluation more than lower-quality extensions damage them. Furthermore, Heath et al. find that the negative quality-associations effects of lower quality extensions can be tempered by perceived brand innovativeness.

\section{Consumer evaluation of vertical extensions}

When it comes to the extension evaluation processes, there is general agreement that the attitude toward a brand name transfers to both category and line extensions through stimulus generalization processes that depend on perceptions of fit between the new product and the brand (Till \& Priluck, 2000). The brand extension literature shows that the higher the fit, the higher will be the transference of beliefs and attitudes from the brand to the extension, which improves both the parent brand's image (John, Locken, \& Joiner, 1998; Loken \& John, 1993) and the extension attitude (Boush \& Loken, 1991; Klink \& Smith, 2001; Völckner \& Sattler, 2006).

By definition, vertical extensions are conceptually similar or closely related to the core 
brand, since they involve the extension to products within the same product category, at different price-quality points. Consistently, according to Michel and Salha (2005), the main influences on vertical extension evaluation are the brand concept and the congruency between the price of the extension product and the price-quality image of the parent brand, relative to the competition. Consumers will accept a vertical extension which is consistent with the core associations of the parent brand, in terms of its price, quality and status positioning (see also Desay \& Hoyer, 1993; Tafani, Michel, \& Rosa, 2009).

Vertical extensions of luxury brands

The effect of brand concept consistency on the evaluation of brand extensions is an issue frequently tackled in the brand extensions literature although, as already noted in the Introduction, only few studies have addressed this in the context of the vertical extension of luxury brands.

In the horizontal brand extension literature, researchers agree that luxury brands can be successfully extended across diverse product categories, provided that their brand concept in terms of symbolic associations and exclusivity are retained in the extended product (Bhat \& Reddy, 2001; Broniarczyk \& Alba, 1994; Liu \& Choi, 2009; Park, Milberg, \& Lawson, 1991).

However, as Randall et al. (1998) note, maintaining brand associations related to prestige and exclusivity can be a difficult task, if the company launches vertical extensions targeting a lower-end of the market. Consequently, prior studies on vertical extensions of luxury brands have been particularly concerned with the effect of such extensions on core brand associations, with general agreement that downscale extensions can be damaging to the parent brand's associations with luxury (Hennigs, Wiedmann, Behrens, Klarmann, \& Carduck, 2013; Kim et al., 2001; Magnoni \& Roux, 2012). 


\section{Hypotheses and model development}

As already noted in the Introduction, extending a luxury brand downward presents specific challenges. Consumers may consider a lower priced line extension as ill-fitting with the price/quality and price/ status association characteristic of a luxury brand's positioning, lowering the evaluation of and the value attributed to the new product, particularly if the low price makes it available to the masses (Heath et al., 2011; Kim et al., 2001; Lei et al., 2008a; Michel \& Salha, 2005). On the other hand, the parent brand's high quality associations may continue to have a positive effect on the evaluation of downscale vertical extensions and on the perceived value for money of the new lower priced product (Liu \& Choi, 2009). Thus, understanding how step-down vertical extensions of luxury brands are judged and valued by consumers is not straightforward (Heath et al., 2011; Liu \& Choi, 2009). To help our understanding of these relationships, we test a number of hypotheses, first overall then controlling for the effect of three conditions (brand type, product category and price). Our structural model is depicted in Figure 1.

\section{Figure 1 - Proposed model}

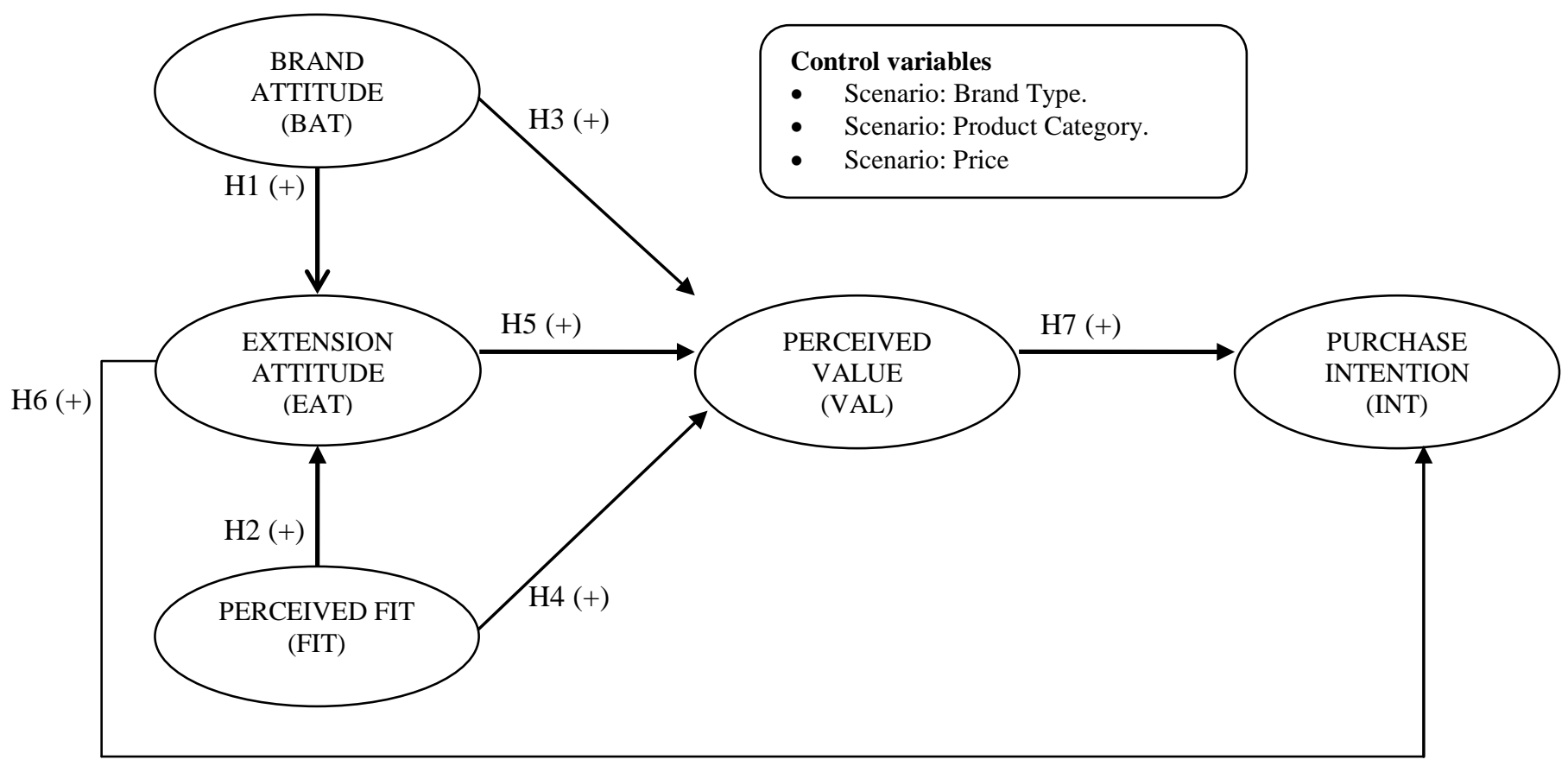




\section{Main paths}

Some of the relationships depicted in Figure 1 have been extensively investigated in the literature on category extensions which, as noted in the Introduction, have been the focus of most brand extensions research. In contrast, the specific challenges presented by the vertical extensions of luxury brands have not been adequately addressed by the extant literature, particularly with regards to whether consumers would value the lower priced product positively, even if its increased affordability may lower its perceptions of exclusivity. Hence we considered it important to test the relationships between brand attitude, perceived fit, extension attitude and consumers' perceived value in the context of downscale vertical extensions of luxury brands. We also test the mediating role of perceived value on consumers' intentions to purchase such extensions. Having tested the overall model, we could then proceed to examine the extent to which different conditions (brand type, product category and price) affect the main relationships in the model in Figure 1.

The essence of extension strategies is the attempt to leverage positive consumer attitudes towards a brand on new products carrying the same brand name. Accordingly, many studies have investigated the impact of consumers' attitudes towards the parent brand on the evaluation of extensions (e.g. Aaker \& Keller, 1990; Bhat \& Reddy, 2001; Grime et al., 2002; Keller \& Aaker, 1992; Reddy et al., 1994 and many others since). Recently, Gierl and Huettl (2011) have confirmed brand attitude transfer as the main process underlying brand extension evaluation. In contrast, relatively few studies have investigated the effect of brand attitude in the context of vertical extensions (Kim \& Lavack, 1996; Kim et al., 2001; Kirmani et al., 1999; Musante, 2007). Drawing from this literature, for vertical extensions of luxury brands, a positive attitude 
towards the parent brand should be conducive to a positive evaluation of its extensions. Hence, our first hypothesis states:

H1. Attitude towards the parent brand (brand attitude) is positively related to the attitude towards a downscale vertical extension (extension attitude).

As Kapoor and Heslop (2009) note, the positive transfer of associations between the parent brand and its extension also depend upon the 'fit' between the two. Indeed, extant research has consistently identified fit as the main factor considered by consumers in the evaluation of both line and category extensions (e.g. Aaker \& Keller, 1990; Bhat \& Reddy, 2001; Boush \& Loken, 1991; Desai \& Hoyer, 1993; Kim et al., 2001; Sattler, Völkner, Riediger, \& Ringle, 2010; Völkner \& Sattler, 2006), since fit perceptions can be formed through different cues, not only category membership, but also in terms of the consistency with the parent brand image (Lei et al., 2008a). Indeed, according to Broniarczyk and Alba (1994, cited in Batra, Lenk, \& Wedel, 2010:336), 'fit at the level of imagery is often a greater determinant of brand extension success than the degree of favourable overall attitudes toward the extending brand'. Although there is a danger that consumers may perceive a lack of fit between a luxury brand image and its downscale vertical extension, according to Völkner \& Sattler (2006) successful brand extensions of any kind are dependent upon the fit between the core brand and its extension. In general, therefore, the higher the perceived fit between the brand and its extension, the higher the extension evaluation. Hence we hypothesise:

H2. Perceived fit is positively related to the attitude towards a downscale vertical extension.

Besides the direct influence of brand attitude on extension attitude, some studies suggest that brand attitude should directly affect the perceived value of an extension (e.g. Martinez \& Pina, 2003; Musante, 2007). Value is generally defined in terms of value for money or the trade- 
off between expected benefits and cost (e.g. Grewal, Monroe, \& Krishnan, 1998; Zeithaml, 1988). One of the benefits consumers derive from the downscale vertical extension of a luxury brand is the opportunity to acquire a status brand at a lower price. On the other hand, associated 'costs' of the downscale vertical extension of a luxury brand could be the perceived lower quality and/or the loss of exclusivity deriving from the fact that the brand becomes accessible to a larger consumer segment. However, a highly positive attitude towards the parent brand is likely to have a reassuring effect on consumers' perceptions of the value of a lower priced vertical extension. Consumers should value a lower priced extension of a high quality, luxury brand. Therefore, we postulate:

H3. Brand attitude is positively related to the perceived value of a downscale vertical extension.

In the general extension literature, perceived fit is found to affect not only the extension attitude, but also the perceived value of the extension (Martinez \& Pina, 2003; Musante, 2007). However, a downscale vertical extension of a luxury brand could be considered as ill-fitting with the brand's price/quality and price/status associations, resulting in lower perceived value of the new product. On the other hand, if the quality/ image consistency between the parent brand image and its downscale extension is retained, consumers would have the opportunity to acquire a status brand at a lower price and would therefore benefit in this way from the extension. This benefit would increase the value of the downscale extension for consumers. Hence, the higher the perceived fit between the brand and its extension, the higher the perceived extension value. Therefore we postulate:

H4. Perceived fit is positively related to the perceived value of a downscale vertical extension.

In previous research, the perceived value of an extension has been found to be affected not only by the parent brand attitude and by the perceived fit between the parent brand and the 
extension, but also by the extension attitude (Hansen \& Hem, 2004; Taylor \& Bearden, 2002).

As Lei et al. (2008a: 271) explain:

'Consumer evaluation of an extension summarizes the overall benefits that consumers expect to receive from a product ... These benefits positively contribute to consumers' perceived value of a product.... Therefore, the higher the evaluation (expected benefits) of an extension, the perceived value of the extension will be higher.'

Hence our fifth hypothesis states:

H5. Extension attitude is positively related to the perceived value of a downscale vertical extension.

Previous literature has sometimes considered purchase intention as one of the possible evaluation criteria of brand extensions (e.g.de Ruyter \& Wetzels, 2000; Keller \& Aaker, 1997), rather than as the behavioural outcome of positive extension evaluation. Since an individual's intention is one of the best predictors of actual behaviour (Davis \& Venkatesh, 1996), de Ruyter and Wetzels (2000) advocate that the drivers of consumer purchase intentions should also be investigated. The few researchers who have considered this issue suggest a direct impact of the extension attitude on consumer behaviour toward the extension, including purchase intention (e.g. Czellar, 2003; Hansen \& Hem, 2004; Martin \& Stewart, 2001). Therefore we hypothesise: H6. Extension attitude is positively related to the intention to purchase a downscale vertical extension.

In this study, we investigate the association of the perceived value of downscale vertical extensions with respondents’ purchase intentions and its role as a mediator between brand attitude, extension attitude, fit and purchase intentions. Heath et al. (2011: 17) note the complexity of vertical extensions' evaluations, involving a number of multiple processes 'that 
sometimes work in concert, sometimes in opposition'. In the instance of the downscale vertical extensions of luxury brands, opponent processes may occur, whereby lower-priced extensions produce both negative association effects and offsetting positive value effects. The lower price of a downscale vertical extension of a luxury brand could be valued positively in terms of value for money, compared with equivalent products from other luxury brands, but could also be valued negatively in terms of the loss of exclusivity derived from a more affordable price. However, in several contexts unrelated to brand extensions, previous research has consistently identified a positive association between perceived value and purchase intention (e.g. Grewal et al., 1998; Sweeney \& Soutar, 2001) and consumers’ purchase behaviour in general (Kleijnen, de Ruyter, \& Wetzels, 2007; Lei, Dawar, \& Lemmink, 2008). Furthermore, positive brand attitudes and extension evaluations which positively affect the perceived value of the downscale vertical extension (H3 to H5) would ensure a positive relationship between perceived extension value and purchase intention. Hence, on balance, we postulate:

H7. Perceived value is positively related to the intention to purchase a downscale vertical extension.

\section{Control variables}

Previous researchers have suggested that a number of possible factors related to the characteristics of the parent brand, of the extension and of the consumer may affect the relationships between brand attitudes, extension attitude, fit, perceived extension value and purchase intentions (e.g. Czellar, 2003; Desay \& Hoyer, 1993; Grime et al., 2002; Hamilton \& Chernev, 2010; Liu \& Choi, 2009). The effects of these factors are complex and no single empirical study has considered them in a comprehensive manner (Grime et al., 2002; Heath et al., 2011). 
In this study we explicitly consider the characteristics of the parent brand (type of brand), the product category and the price differential between the parent brand and its vertical extension. We examine the structural relationships depicted in Figure 1 under different scenarios, hence controlling in turn for the parent brand type, the product category and the price differential between the parent brand and the vertical extension.

In the next sub-sections we discuss these variables and, where possible, outline expectations on their likely effect on the relationship in the structural model.

\section{Brand type}

As mentioned in the Introduction, a number of studies have compared functional and luxury brands with regards to consumers’ evaluation of vertical extensions (e.g. Kim \& Lavack, 1996; Kim et al., 2001; Kirmani et al., 1999), but have not acknowledged that brands vary on a continuum of prestige and price (De Barnier et al., 2012; Reddy et al., 2009; Truong et al., 2009), as well as status and conspicuousness (Truong et al., 2008; Vigneron \& Johnson, 2004). For example, Reddy et al. (2009) differentiate between luxury brands and premium brands; for both luxury and premium brands quality is important, but the price is lower and distribution is less selective for premium than for luxury brands. In this study we adopt Reddy et al.’s (2009) categorization and consider the parent brand type (luxury vs. premium) as a control variable for testing the structural relationships in the model depicted in Figure 1.

Since extant literature has only considered the distinction between functional and prestige brands, we can only draw on this literature when outlining expectations with regards to the effect of the brand concept.

According to Park et al. (1991), for both functional and luxury brands, consumers evaluate extensions more positively when there is concept consistency and product feature similarity with 
the parent brand. Moreover, Kirmani et al. (1999) found that introducing a vertical extension with a $40 \%$ discount on the initial price leads to more negative evaluations for a luxury brand than for a functional brand. From this we can deduce that, for all types of brands, concept consistency and product feature similarities with the parent brand are important in the evaluation of vertical extensions. However, the importance of concept consistency on extension attitude and extension perceived value of a vertical extension should increase, the higher a brand is positioned on the continuum of prestige, price, status and conspicuousness. Consumers may consider a downscale vertical extension as inconsistent and incompatible with the dominant concept in their minds of a luxury brand as a status symbol (Desai \& Hoyer, 1993). Furthermore, a substantially lower price renders the brand accessible to a larger consumer segment, lowering the status evaluation of the luxury brand's downscale extension (Kim et al., 2001; Lei et al., 2008a). On the other hand, since the price of premium brands is already lower and their distribution is less selective than for luxury brands, maintaining the consistency between the brand and its lower priced extensions should be less problematic for premium than for luxury brands. In other words, we expect that fit should have greater importance for luxury than for premium brands; similarly extension attitude should have a stronger role on the perceived extension value of a luxury than of a premium brand. From this, it also follows that the relationship between perceived extension value and purchase intention should also be stronger for luxury than for premium brands.

On the other hand, both luxury and premium brands are positioned highly in terms of quality and, for both types of brands, the transfer of brand quality perceptions to their vertical extensions is crucial in the evaluation of such extensions and of their value (actually as it would be for non-luxury brands; e.g. see Albrecht et al., 2013). It is also logical to expect that a positive 
extension attitude will have a similarly positive impact on consumers' purchase intentions for both luxury and premium brands. Hence we expect that the association of brand attitude with extension attitude and with perceived extension value will be similar for luxury and for premium brands. Similarly, the relationship between extension attitude and purchase intention should be similar for luxury and premium brands.

\section{Product category}

While both cars and fashion products are public necessities (Bearden \& Etzel, 1982), in terms of visibility cars are usually more conspicuous to reference groups than fashion (shoes) (e.g. Bourne, 1957). Driving a cheaper model of a luxury or premium car brand (e.g. a cheaper Porsche or a cheaper Audi model) is more obvious to reference groups than wearing a cheaper shoe from a luxury or a premium brand (e.g. a cheaper Prada or a cheaper Diesel shoe). In the latter instance, the cachet deriving from the luxury/premium brand is likely to remain intact, since peers may still be shown the branded shoe, but may not be able to identify a cheaper model. But in the case of a cheaper version of a luxury/ premium car both the model and the brand are highly visible and recognisable. Therefore, the social risk (DelVecchio \& Smith, 2005; Liu \& Choi, 2009) stemming from wearing a cheaper shoe is lower than when driving an obviously cheaper model of a luxury/ premium brand. This reasoning is also coherent with the popularity among consumers of counterfeit luxury fashion brands, even when consumers are aware that what they have bought is a fake (e.g. Gentry, Putrevu, Shultz, \& Connuri, 2001; Nia \& Zaichkowsky, 2000).

While we do not measure the social risk associated with the respective downscale vertical extensions, it is logical to assume that for car brands, which are very conspicuous and recognisable by peers, extension evaluation and the perceived value of a downscale vertical 
extension will be more reliant on associations of fit with the usual range of products offered by the parent brand. Hence we expect that the association of fit with extension attitude and with perceived value will be stronger for cars than for fashion shoes.

With regards to the effects of the product category on the relationship between brand attitude, extension attitude and perceived extension value, for product categories like fashion where the range of products on offer is wider and more varied in terms of price ranges, downscale extensions should be more acceptable than the equivalent downscale extensions of brands within a conspicuous product category like cars with narrow ranges. This reasoning is consistent with Desai and Hoyer's (1993) proposition that the degree of differentiation within a product category has an impact on the acceptance of an extension. It follows that in product categories like fashion where there is a wide range of products and prices, it is the overall attitude toward the brand (rather than the fit) which will be important in shaping the extension evaluation and the perceived value of the extension. We also expect that the relationships between extension attitude, perceived value of the extension and purchase intention should be stronger for less conspicuous products like fashion shoes than for more conspicuous products like cars.

Del Vecchio and Smith (2005) found that perceived fit is more relevant for consumers when social risk is high, which influences consumers' willingness to pay for the extension. Social risk increases to the extent that the product is visibly branded and may lead consumers to focus more on the brand associations and perceived fit, particularly in the case of a higher differentiation within the product category (Desai \& Hoyer, 1993). On the contrary, the assessment and purchase intentions of product categories with lower brand relevance should be mainly dependent on the specific attitude toward the extension. 
Hence we expect that the association of brand attitude to extension attitude and to perceived extension value will be stronger for fashion shoes than for cars. Similarly, extension attitude should be more strongly associated to purchase intention and perceived extension for fashion shoes than for cars. Finally, we expect this to be the case also with regards to the relationship between perceived extension value and purchase intention.

\section{Price (discount size)}

By definition, vertical extensions are closely related to the core brand, since they involve the extension to products within the same product category. However, what varies is the price (and by consequence perhaps the inferred quality) of the vertical extension. Consistently, according to Michel and Salha (2005), the main factors determining vertical extensions evaluation will be the brand concept and the congruency between the price of the extension product and the pricequality image of the parent brand, relative to the competition. Consumers will accept a vertical extension which is consistent with the core associations of the parent brand, in terms of its price and quality positioning (see also Desai \& Hoyer, 1993).

Michel and Salha (2005) also note that the possible loss of coherence between the vertical extension and the quality-price perception of the core brand is avoidable by signaling to the consumer that the new extension product is in an all-together different market segment from the existing products. A substantially lower price for the extension product can provide this kind of signal. At the same time, one of the core brand associations must be transferable and relevant in the new extension context, if the extension is to be evaluated positively. However, when it comes to assessing the evaluation of the vertical extension, Musante (2007: 60) argues that 'the greater the difference between the brand's traditional price range and the price positioning of the new product the less the perceived fit is'. Similarly, Taylor and Bearden (2002) find that price 
information has a large negative impact on perceived value and purchase intentions for similar extensions.

Overall, the effect of the magnitude of the price differential between a brand and its downscale vertical extension is not clear. Price is a complex variable that can exert a dual role by increasing both perceptions of monetary sacrifice and perceptions of quality (Erickson \& Johansson, 1985; Leavitt, 1954; Rao \& Monroe, 1988). Moreover, usually price is not assessed as an isolated item but in comparison with either a reference price or a price distribution, such as the endpoint prices of the brand portfolio (Niedrich, Sharma, \& Wedell, 2001; Niedrich, Weathers, Hill, \& Bell, 2009). In the specific case of vertical extensions, we could expect that consumers assess the congruency between the price of the new product and the price-quality image of the parent brand rather than the price itself (Michel \& Salha, 2005). Moreover, Hamilton and Chernev (2010) show that vertical extensions modify the beliefs that a specific retailer competes in a determined price range.

Given the lack of consistent literature on the role of price as a control variable, we do not formulate any specific expectations at this point. However, price constitutes a key signal to infer the fit between the brand and the new product and it is thus likely to exert some effect. For example, consumers might judge a vertical extension priced 50\% below the usual price range of a luxury/ premium brand as more incongruous than a vertical extension with a 25\% discount. This could indirectly lead to a decrease in fit perceptions. In this case, the evaluation of the vertical extension may be based on the attributes of the new product rather than on the attitude toward the parent brand (Boush \& Loken, 1991; Kim et al., 2001). That is to say, in our model, the perceived value and purchase intention factors would be more strongly associated to the extension attitude than to the brand attitude. However perceived fit is also built upon factors 
other than price such as, for instance, the product category, hence it is difficult to make a sound prediction of the final effect of price.

\section{Methodology}

Adopting a commonly used procedure, the research design of the empirical part of this study involved the analysis of real brands and of realistic hypothetical extensions (e.g. Aaker \& Keller, 1990; Albrecht et al., 2013; Kim et al., 2001; Kirmani et al., 1999). The methodology for the study is explained in detail below.

Pre-test

Firstly, a pre-test was conducted with the aim of choosing one luxury and one premium brand in each of the following product categories: cars and fashion (shoes). Both categories have attracted the interest of previous researchers in this field (e.g. Kim et al., 2001; Matthiesen \& Phau, 2010). In both product categories there is a wide range of well established brands at different price and position on the prestige, status and conspicuousness continuum. This is useful in terms of selecting well-known luxury and premium brands that might be stretched down to new products. Moreover, there are several examples of real vertical extensions of luxury/premium cars and of luxury/premium fashion brands which have maintained the main brand as an umbrella and have not felt the need to adopt a house of brands strategy when extending downwards. Examples include Mercedes’ Class A cars or BMW 1 series. Similarly, Armani has adopted a sub-branding strategy, with Emporio Armani and Armani Exchange, but with the Master Brand Armani as a Driver (see Aaker \& Joachimsthaler, 2000). Finally, as noted in the Introduction, cars and fashion shoes brands (and their extensions) do differ in the extent to which they are conspicuous and recognizable. 
A convenience sample of 50 postgraduate students (46 valid data) at a UK Business School participated in the pre-test. The use of university students in pre-tests is common practice (e.g. Kim et al., 2001; Sheinin \& Schmitt, 1994). Respondents stated their familiarity (FAM) and rated the prestige (PRE) of ten car brands (Alfa Romeo, Aston Martin, Audi, BMW, Ferrari, Maserati, Range Rover, Saab, Porsche, Volvo) and ten fashion brands (Abercrombie \& Fitch, Diesel, French Connection, Givenchy, Gucci, Guess, Lanvin, Levi’s, Louis Vuitton, Prada) through 7-point scales (1=totally unfamiliar/ 7= very familiar; $1=$ not very prestigious/ 7=very prestigious). The list of car brands originated from car magazines' classification of cars at the upper end of the market, mainly on the basis of price ranges above the median. The list of fashion brands stemmed from the examination of both online and offline retailers, to identify clothing brands at the upper end of the price-quality range. The upper end of the price-quality range was considered, with the aim of avoiding a floor effect in the selection of the potential downscale vertical extensions. In practical terms, the selected brands were required to be expensive enough to accommodate downscale vertical extensions with different degrees of discount, up to $50 \%$.

The procedure for selecting the brands consisted of three steps that were independently performed for each product category. First, we discarded those brands that were considered inadequate due to factors such as low familiarity ratings (below the median point 4 on the familiarity scale) or high variability in responses (i.e. those brands which different respondents perceived as positioned differently on the prestige scale). Secondly, the brands were ranked according to the average prestige and the one with the highest score was chosen as the "luxury" brand. Third, the luxury brand was compared to the subsequent names on the list and the first case with clear statistical differences in prestige (at 99\% confidence interval) was kept as the 
"premium" brand. The pre-test thus resulted in the selection of Porsche (FAM=6.28; PRE=6.29) and Prada (FAM=6.10; PRE=6.63) as the luxury brands and Audi (FAM=6.54; PRE=5.61) and Diesel (FAM=6.24; PRE=5.33) as the premium brands in their respective product categories. The four brands met the criteria of achieving scores above the median (4) in the familiarity and prestige questions. Moreover, there were no statistical differences in familiarity ratings for either cars $(\mathrm{p}=0.85$ ) or fashion brands ( $\mathrm{p}=0.93)$. As expected, the prestige variable was rated higher for Porsche and Prada $(\mathrm{p}<0.01)$ than for Audi and Diesel. In the remaining part of the paper, we will thus employ the term luxury brand for Porsche/Prada and premium brand for Audi/Diesel. This denomination is also consistent with Truong et al.’s (2009) and Reddy et al.’s (2009) classification of luxury brand types.

\section{Questionnaire design}

A 2 × 2 × 2 research design was adopted; this allowed us to test the effects of brand type (luxury vs. premium), product category (cars vs. fashion shoes) and price (-25\% vs. $-50 \%$ ) on the main relationships of the model. Accordingly, subsequent to the pre-test, the main study included 8 questionnaire versions with a different brand-extension combination. Each questionnaire focused on one brand and either a $25 \%$ or a $50 \%$ fictitious vertical downscale extension.

For all questionnaires, the opening questions regarded consumer expertise with the product category and parent brand measurements (familiarity, brand concept, brand attitude). Then, individuals read a statement similar to those employed in previous research (Kirmani et al., 1999; Musante, 2007), for example: 'PORSCHE is considering the introduction of a new soft top car model, at a price of $£ 25,278$. This new model would be the first to be priced $25 \%$ below the current price range of $£ 33,704$ to $£ 130,791$ '. Immediately afterwards, individuals were asked to indicate perceived fit and their assessment of the new product (attitude towards the extension, 
perceived extension value, purchase intention). The questionnaire ended with other questions not considered in this paper and classification questions related to gender, age and annual household income.

\section{Data collection}

The questionnaires were administered through a mall intercept, quota sampling method. The fieldwork took place in Greater London, including upmarket shopping centres and the Canary Warf financial district, with the aim of capturing a sample reflecting the upper income segments of the population. The quota sample structure for each questionnaire attempted to reflect the UK population in terms of gender and age. Ultimately, the following segments were obtained, approximately reflecting the gender and age of the UK population of working age (UK Office for National statistics, 2014): male (49\%), female (51\%); 18 to 44 (72\%), 45 to 64 (28\%). In terms of income, the characteristics of the sample were as follows: $<£ 20,000$ (15\%), £20,000-£30,000 (24\%), £30,001-£40,000 (26\%), £40,000+ (35\%). Given that, at the time of the data collection, the median wage in the UK for all jobs was about $£ 20,800$ (Rohrer, 2009) the location of the fieldwork did succeed in providing a sample of the population belonging to the higher income groups. This contributed to the external validity to our study, which focused on luxury and premium brands.

Finally, each brand/extension combination was randomly assigned to respondents, which yielded a similar number of surveys (around 30).

After excluding the questionnaires with many missing values or repeated responses, we obtained a dataset of 240 cases. The data were subject to a preliminary statistical analysis with SPSS 19.0; first, boxplots of all variables were obtained to detect univariate outliers; second, the questionnaires with outliers were thoroughly revised to rule out the existence of patterns of 
incongruence between answers (e.g. extremely positive values for brand image and extremely negative values for the brand attitude). These procedures led to the deletion of four questionnaires (resulting in 236 valid answers). Finally, common-method bias was examined by means of the Harman test, which was conducted through confirmatory factor analysis with EQS 6.1. As expected, this test showed that the goodness of fit of a model where all the variables loaded on a single construct was substantially worse than the goodness of fit of a model where every item was attached to its respective latent variable.

\section{Measures}

Except for demographic information, the variables in this study were measured via 7-point scales, with items based on previous literature. Table 1 displays the variables used in the questionnaires by specifying the items which form each scale and their source.

First, customer expertise was measured with three items proposed by Mishra, Umesh, and Stem (1993), relating to the respondents' general knowledge, experience and information about the product category. The scale of brand familiarity (FAM) included a single item (Milberg, Park, \& McCarthy, 1997). The perceived parent brand concept (PBC) and the extension concept (BEC) each comprised two items which aimed to measure the prestige and the luxury characteristics of the parent brand and of the extension, respectively (Lei et al., 2008a). The measurement for both the attitude toward the parent brand (BAT) (Musante, 2007) and attitude toward the extension (EAT) (Kirmani et al., 1999; Musante, 2007) were also similar, so that to guarantee the theoretical consistency of the constructs. Three items were adapted from previous literature and considered if the consumer's attitude was favourable and he/she liked the parent brand and the new product and found them appealing. 
Table 1 - Scales used in the research

\begin{tabular}{|c|c|c|}
\hline Scale & Items & Source \\
\hline $\begin{array}{l}\text { Customer } \\
\text { Expertise }\end{array}$ & $\begin{array}{l}\text { EXP1 - Knowledge about product in general } \\
\text { EXP2 - Inexperienced / Experienced } \\
\text { EXP3 - Uninformed / Informed }\end{array}$ & $\begin{array}{l}\text { Mishra, Umesh, \& Stem } \\
\text { (1993) }\end{array}$ \\
\hline Brand Familiarity & FAM - Not familiar / Familiar & $\begin{array}{l}\text { Milberg, Park, \& McCarthy } \\
\text { (1997) }\end{array}$ \\
\hline $\begin{array}{l}\text { Parent Brand } \\
\text { Concept }\end{array}$ & $\begin{array}{l}\text { PBC1 - Budget/Luxury } \\
\text { PBC2 - Functional/Prestige }\end{array}$ & $\begin{array}{l}\text { Lei, deRuyter, \& Wetzels } \\
\text { (2008a) }\end{array}$ \\
\hline Brand Attitude & $\begin{array}{l}\text { BAT1 - Unfavourable / Favourable } \\
\text { BAT2 - Dislike / Like } \\
\text { BAT3 - Unappealing / Appealing }\end{array}$ & Musante (2007) \\
\hline $\begin{array}{l}\text { Perceived Fit of } \\
\text { Extension }\end{array}$ & $\begin{array}{l}\text { FIT1 - Bad Fit / Good Fit } \\
\text { FIT2 - Not logical / Very logical } \\
\text { FIT3 - Not appropriate / Very Appropriate }\end{array}$ & Keller \& Aaker (1992) \\
\hline $\begin{array}{l}\text { General Extension } \\
\text { Attitude }\end{array}$ & $\begin{array}{l}\text { EAT1 - Unfavourable / Favourable } \\
\text { EAT2 - Dislike / Like } \\
\text { EAT3 - Unappealing / Appealing }\end{array}$ & $\begin{array}{l}\text { Musante (2007); Kirmani, } \\
\text { Sood, \& Bridges (1999) }\end{array}$ \\
\hline $\begin{array}{l}\text { Perceived Value } \\
\text { of Extension }\end{array}$ & $\begin{array}{l}\text { VAL1 - Good value for money } \\
\text { VAL2 - Good buy } \\
\text { VAL3 - Comparative Value }\end{array}$ & $\begin{array}{l}\text { Taylor \& Bearden (2002); Lei, } \\
\text { de Ruyter, \& Wetzels (2008) }\end{array}$ \\
\hline $\begin{array}{l}\text { Brand Extension } \\
\text { Concept }\end{array}$ & $\begin{array}{l}\text { BEC1 - Budget/Luxury } \\
\text { BEC2 - Functional/Prestige }\end{array}$ & $\begin{array}{l}\text { Lei, deRuyter, \& Wetzels } \\
\text { (2008a) }\end{array}$ \\
\hline Purchase Intention & $\begin{array}{l}\text { INT1 - Unlikely / Likely } \\
\text { INT2- Would not consider it/ Would consider it } \\
\text { INT3 - Not probable/ Very probable }\end{array}$ & $\begin{array}{l}\text { O’Cass \& Grace (2004); } \\
\text { Lafferty (2007) }\end{array}$ \\
\hline
\end{tabular}

The scale of perceived fit (FIT) included three items that assessed from different angles the coherence between the new product and the parent brand (Keller \& Aaker, 1992). For the perceived value (VAL) construct, three items adapted from Taylor and Bearden (2002) measured if consumers considered the downscale vertical extension as good value for money, a good buy, or valued it as compared with similar products. A three-item scale was also employed to measure the likelihood of purchasing the extension (INT) (Lafferty, 2007; O'Cass \& Grace, 2004).

\section{Results}

Structural equation modelling was the selected method for testing the hypotheses and for conducting multi-group analysis comparing the effect of the different conditions. Specifically, Partial Least Squares (PLS) was used by employing the software SmartPLS 2.0 M3 (Ringle, 
Wende, \& Will, 2005). The PLS approach to structural equation modelling was chosen for several reasons. Firstly, PLS path modelling is component based and does not require multivariate normal data, has minimum requirements on measurement levels and can deal with small samples (Chin, 1998; Tenenhaus, Vinzi, \& Chatelin, 2005). As shown in the Appendix, some of the survey items have problems of either kurtosis or skewness, which makes advisable to use methodologies that do not require the normality assumptions. Furthermore, the focus of PLS is on prediction and theory development, hence it is best suited for exploratory research where the effects of different conditions are tested (Hair, Hult, Ringle, \& Sarstedt, 2014). In this sense, the analysis of the control variables (brand type, product category, and price) may be considered as exploratory. Finally, PLS has recently been applied in similar studies of brand extensions, in the context of services brands (e.g. Boisvert, 2012; Lei et al., 2008a; Völckner, Sattler, Hennig-Thurau, \& Ringle, 2010).

The PLS procedure involved an initial stage of testing the psychometrical properties of the measurement model and a subsequent stage of estimating the paths between the constructs, determining their significance as well as the predictive ability of the model overall, for the whole set of data (Hulland, 1999). In the third stage of the study, we conducted a series of multi-group analyses each of which controlled for the brand characteristics, the product category and price.

\section{Scale validation and statistical checks}

The appropriateness of the measurement model was determined by examining the psychometric properties of uni-dimensionality, reliability and validity. An initial exploratory analysis with SPSS checked the reliability property and dismissed the likelihood of underlying sub-dimensions within the proposed factors. The subsequent PLS estimation provided additional results in favour of the proposed measurements. All the standardized loadings of the individual items on their 
constructs were significant and above 0.7, in line with the guidelines given by Hair, Black, Babin and Anderson (2010). The thresholds established for constructs' reliability and validity were also exceeded. As shown in Table 2, Cronbach’s alpha values and composite reliability coefficients (CRC) are higher than 0.9 in all cases, which indicate excellent reliability. All AVEs coefficients are also highly above the cut off of 0.5 , which provides convergent validity (Fornell \& Larcker, 1981). Finally, discriminant validity was demonstrated since the square roots of the AVEs are greater than the correlations between the factors (Chin, 1998).

Table 2 - Reliability and validity of the factors

\begin{tabular}{|c|c|c|c|c|c|c|c|c|}
\hline \multirow[t]{2}{*}{ Scale } & \multirow{2}{*}{$\begin{array}{c}\text { Cronbach } \alpha \\
(>0.7)\end{array}$} & \multirow{2}{*}{$\begin{array}{l}C R C^{a} \\
(>0.6)\end{array}$} & \multirow{2}{*}{$\begin{array}{l}A V E^{b} \\
(>0.5)\end{array}$} & \multicolumn{5}{|c|}{ Construct correlation matrix ${ }^{\mathrm{c}}$} \\
\hline & & & & BAT & FIT & EAT & $V A L$ & INT \\
\hline $\begin{array}{l}\text { Parent Brand } \\
\text { Attitude (BAT) }\end{array}$ & 0.916 & 0.947 & 0.856 & 0.925 & & & & \\
\hline $\begin{array}{l}\text { Perceived Fit of } \\
\text { Extension (FIT) }\end{array}$ & 0.923 & 0.952 & 0.868 & 0.051 & 0.932 & & & \\
\hline $\begin{array}{l}\text { General Extension } \\
\text { Attitude (EAT) }\end{array}$ & 0.947 & 0.966 & 0.905 & 0.374 & 0.501 & 0.951 & & \\
\hline $\begin{array}{l}\text { Perceived Value of } \\
\text { Extension (VAL) }\end{array}$ & 0.947 & 0.966 & 0.904 & 0.351 & 0.363 & 0.614 & 0.951 & \\
\hline $\begin{array}{l}\text { Purchase Intention } \\
\text { (INT) }\end{array}$ & 0.957 & 0.972 & 0.921 & 0.481 & 0.278 & 0.651 & 0.713 & 0.959 \\
\hline
\end{tabular}

${ }^{a}$ CRC: Composite Reliability Coefficient; ${ }^{b}$ AVE: Average variance extracted ${ }^{c}$ Square root of AVE is on the diagonal of the construct correlation matrix

Apart from this check for the suitability of the measurement procedures, prior to the testing of the structural model some additional analyses were carried out. Specifically, it was confirmed that each brand obtained a familiarity score above the median (4) and that the average parent brand concept (PBC) was above the average extension concept (BEC) for both cars ( $\mathrm{t}=8.85$; $\mathrm{p}=0.00)$ and fashion $(\mathrm{t}=4.36 ; \mathrm{p}=0.00)$. This result indicates that respondents viewed the new products as real downscale extensions in terms of quality-price, as proposed by Lei et al. (2008a). As expected, PBC was also higher for the luxury (6.17) than for the premium brands (4.95; $\mathrm{p}=0.00)$. 


\section{Main paths of the model estimation}

Contrary to traditional covariance-based SEM models, PLS estimations do not provide a battery of indexes on the internal validity of the models and it focuses on their predictive ability.

Evaluating the structural model involves examination of $\mathrm{R}^{2}$ values and Stone-Geisser $\left(\mathrm{Q}^{2}\right)$ index for the dependent variables (extension attitude, perceived extension value and purchase intention), the statistical significance of the paths of the model, and GoF index for predictive relevance of the overall model. Results related to the structural relationships are shown in the top part of Table 3.

Table 3 - Results of the structural model estimation

\begin{tabular}{|c|c|c|c|}
\hline Hypotheses & \multicolumn{2}{|c|}{ Standardized $\beta$} & $\begin{array}{l}\text { t-value } \\
\text { (bootstrapping 5000) }\end{array}$ \\
\hline \multicolumn{4}{|l|}{ MAIN PATHS } \\
\hline EXTENSION ATTITUDE & \multicolumn{2}{|c|}{$\mathrm{R}^{2}=0.373$} & \\
\hline Brand attitude $\rightarrow$ Extension attitude (H1) & \multicolumn{2}{|c|}{0.349} & $5.59 *$ \\
\hline Perceived fit $\rightarrow$ Extension attitude (H2) & \multicolumn{2}{|c|}{0.483} & $7.34 *$ \\
\hline PERCEIVED VALUE & \multicolumn{2}{|c|}{$\mathrm{R}^{2}=0.402$} & \\
\hline Brand attitude $\rightarrow$ Perceived value (H3) & \multicolumn{2}{|c|}{0.158} & $2.29 *$ \\
\hline Perceived fit $\rightarrow$ Perceived value (H4) & \multicolumn{2}{|c|}{0.103} & 1.38 \\
\hline Extension attitude $\rightarrow$ Perceived value (H5) & \multicolumn{2}{|c|}{0.504} & $5.93 *$ \\
\hline PURCHASE INTENTION & \multicolumn{2}{|c|}{$\mathrm{R}^{2}=0.581$} & \\
\hline Extension attitude $\rightarrow$ Purchase intention (H6) & \multicolumn{2}{|c|}{0.343} & $4.89 *$ \\
\hline Perceived value $\rightarrow$ Purchase intention (H7) & \multicolumn{2}{|c|}{0.502} & $7.56^{*}$ \\
\hline \multicolumn{4}{|c|}{ MEDIATING PATHS } \\
\hline \multicolumn{3}{|c|}{ Brand attitude $\rightarrow$ Perceived value $\rightarrow$ Purchase intention } & (partial mediation) \\
\hline \multicolumn{2}{|c|}{ Extension attitude $\rightarrow$ Perceived value $\rightarrow$ Purchase intention } & \multicolumn{2}{|c|}{ VAF $=56.3 \%$ (partial mediation) } \\
\hline \multicolumn{2}{|c|}{ Perceived fit $\rightarrow$ Perceived value $\rightarrow$ Purchase intention } & \multicolumn{2}{|c|}{ No mediation (H4 is not supported) } \\
\hline \multicolumn{2}{|c|}{ Brand attitude $\rightarrow$ Extension attitude $\rightarrow$ Perceived value } & \multicolumn{2}{|c|}{$\mathrm{VAF}=55.2 \%$ (partial mediation) } \\
\hline \multicolumn{2}{|c|}{ Perceived fit $\rightarrow$ Extension attitude $\rightarrow$ Perceived value } & \multicolumn{2}{|c|}{ VAF $=71.1 \%$ (partial mediation) } \\
\hline
\end{tabular}

The results presented in Table 3 indicate considerable explanatory power of the structural model. $\mathrm{R}^{2}$ values indicate levels of model fit between moderate and substantial (i.e. above the benchmark of .2 suggested by Henseler, Ringle \& Sinkovics, 2009 and between the thresholds of .33 and .67 suggested by Chin, 1998). Furthermore, results of a blindfolding procedure yielded 
predictive relevance $\mathrm{Q}^{2}$ values larger than 0 for each dependent construct, which implies that the model has predictive relevance (Chin, 1998). It is also significant that the global criterion of goodness of fit (GoF index=0.634) doubled the value associated to a large effect size (0.36), which indicates that the PLS model performs well globally (Wetzels, Odekerken-Schröder \& van Oppen, 2009).

The PLS algorithm also provided the path coefficients regarding the proposed hypotheses. The bootstrapping technique with varying number of samples was used to test in a robust way whether or not these paths are significant. Specifically, results reported in Table 3 are based on 5000 samples. Most hypotheses were supported.

First, results reveal that parent brand attitude is positively related to both general extension attitude $\left(\beta_{\text {est }}=0.349 ; \mathrm{t}\right.$-value $\left.=5.59\right)$ and perceived value of the extension $\left(\beta_{\text {est }}=0.158\right.$; $\mathrm{t}-$ value=2.29), which lends support to hypotheses H1 and H3. Hence, consumers holding a favourable attitude toward a brand will rate its downscale vertical extensions positively, both in general terms and also with regards to their comparative value. As predicted in $\mathrm{H} 2$, extension attitude is also positively linked to perceived fit between the new product and the parent brand $\left(\beta_{\text {est }}=0.483\right.$; $\left.\mathrm{t}-\mathrm{value}=7.34\right)$. The results for $\mathrm{H} 1$ to $\mathrm{H} 3$ are thus supported and are consistent with the previous literature.

Contrary to Hypothesis 4, the coefficient regarding the relationship between perceived fit and perceived value of the extension fails to reach enough statistical significance ( $\beta_{\text {est }}=0.103$; tvalue $=1.38$ ). This result suggests that even when the downscale vertical extensions of luxury/ premium brands are considered to be logical and appropriate for the parent brands, fit does not automatically translate into perceptions of value for the extensions themselves. On the other 
hand, perceived extension value is positively associated to general extension attitude ( $\beta_{\text {est }}=0.504$; t-value=5.93). Hypothesis H5 and related literature are thus supported.

The next hypotheses in the model sought to explain the intention to purchase the new product. The results reveal that the intention to purchase downscale vertical extensions is significantly and positively related to both general extension attitude $\left(\beta_{\text {est }}=0.343\right.$; t-value $\left.=4.89\right)$ and perceived value ( $\beta_{\text {est }}=0.502$; $t$-value $\left.=7.56\right)$. Therefore, there is also empirical support in favour of $\mathrm{H6}$ and H7. Perceived extension value appears a stronger determinant of purchase intention than extension attitude, confirming that the ultimate variable guiding consumer behaviour when it comes to vertical downscale line extensions is what consumers get in relation to what they pay.

In summary, apart from the relationship between perceived extension fit and perceived extension value (H4), the results pertaining to all hypotheses fall in line with predictions.

\section{Mediating effects}

Further, we empirically tested the role of perceived value of the downscale vertical extension as mediator of the associations of brand attitude, extension attitude and perceived fit with purchase intention.

To examine mediation effects we followed Hair et al. (2014) who suggest computation of the 'variance accounted for' (VAF) score in order to determine the size of the indirect path in relation to the total path (i.e., direct path + indirect path) ${ }^{1}$. The VAF score determines the extent to which the mediator (perceived extension value) accounts for the relationship between the independent variables (brand attitude, extension attitude and fit) and the dependent variable (purchase intention). According to Hair et al. (2014, p. 225), VAF scores higher than $80 \%$

\footnotetext{
${ }^{1}$ This method is considered appropriate in PLS-SEM due to its use of the standardised path coefficients as input for the test statistic (as compared to the commonly-used Sobel test which uses non-standardised path coefficients).
} 
denote full mediation, scores between $20 \%$ and $80 \%$ indicate partial mediation, while there is no mediation if VAF is below 20\%. Results are reported at the bottom of Table 3.

First we note that since the direct path of fit to perceived value is not statistically significant (H4 was not supported), perceived value does not mediate the relationship between fit and purchase intention. However, taken together, the results relating to $\mathrm{H} 2, \mathrm{H} 4$ and $\mathrm{H} 5$ suggest that the relationship between perceived fit and perceived value is indirect, through the mediating role of general extension attitude. Following bootstrapping of the sampling distribution of the indirect effect, calculation for extension attitude as a mediator between perceived fit and perceived value revealed a VAF score of $71.1 \%$ which, based on the criteria recommended by Hair et al. (2014), indicates a partial mediation. Similarly, extension attitude partially mediates the path of brand attitude to perceived value ( $\mathrm{VAF}=55.2 \%$ ).

Coming back to the mediating role of perceived extension value, the bootstrapping procedure confirms that perceived value does partially mediate both the path of brand attitude $(\mathrm{VAF}=39.1 \%)$ and the effect of extension attitude $(\mathrm{VAF}=56.3 \%)$ to purchase intention. In other words, 39\% of variance between brand attitude and intention and $56.3 \%$ of the variance between extension attitude and intention is explained by the indirect relationship via perceived extension value.

\section{Control variables}

The next stage of the analysis involved controlling for the effect of the brand characteristics (luxury vs. premium), product category (cars vs. fashion shoes) and price (-25\% vs. -50\%) on the global structural model relationships. To this end, we conducted multi-group analysis (PLSMGA) following the parametric approach and making use of bootstrapping standard errors to 
ascertain the statistical differences between the beta coefficients yielded by the PLS algorithm. Results are shown in Table 4.

For both premium and luxury brands, all relationships hypothesized in the structural models are supported, except for $\mathrm{H} 3$ and $\mathrm{H} 4$. For both types of brand, perceived value is not related to either brand attitude (H3) or perceived fit (H4). The latter is consistent with the overall results presented above. The results in Table 4 also show that there are no statistically significant differences at $\mathrm{p}=0.05$ between luxury and premium brands with regards to the strength of the relationships between the variables. As we expected, perceived fit has a stronger association with extension attitude $(E A T)$ for luxury $\left(\beta_{\text {luxury }}=0.549\right)$ than for premium $\left(\beta_{\text {premium }}\right.$ $=0.307)$ brands, although the t-test statistic indicates a significant difference only at the $90 \%$ confidence interval ( $\mathrm{t}$-value diff $=-1.84 ; \mathrm{p}=0.1$ ). Similarly, the expected stronger associations for luxury than for premium brands of extension attitude with perceived extension value and of the latter with purchase intention are in the expected direction, but the differences are not statistically significant.

The results related to the price variable are in line with those obtained for the type of brand. All relationships hypothesized in the structural models are supported, except for $\mathrm{H} 3$ and H4. Again, the latter is consistent with the overall results presented above. No statistical differences are found between the two price level discounts for any of the relationships included in our model. As commented earlier in the paper, it is possible that other factors like perceived fit are able to capture the beliefs resulting from the exposure of consumers to the different price level discounts.

In contrast with the above, the results of the multi group analysis summarized in Table 4 suggest that the product category is a very important factor when it comes to assessing how 
downscale vertical extensions of luxury and premium brands are evaluated. Thus, a number of significant differences emerge when the effect of the product category is considered. Firstly, fit does have a strong significant association to the perceived value of the extension for cars, supporting $\mathrm{H} 4$ for this product category, while there is virtually no relationship between fit and perceived extension value for shoes $\left(\beta_{\text {cars }}=0.332>\beta_{\text {fashion }}=-0.027\right.$; $\mathrm{t}$-value diff $\left.=2.38 ; \mathrm{p}=0.05\right)$. Similarly, fit has a much stronger correlation with extension attitude for cars than for shoes ( $\beta_{\text {cars }}$ $=0.622>\beta_{\text {fashion }}=0.323$; $\mathrm{t}$-value diff $=2.74 ; \mathrm{p}=0.01$ ). These results suggest that fit is a much more prominent factor in the evaluation of the extensions (whether in general or with regards to value) for the downscale vertical extensions of cars, than for fashion shoes.

In contrast, consistent with our expectations, brand attitude (BAT) has a significantly stronger association with the attitude toward the extension (EAT) for fashion shoes than for cars $\left(\beta_{\text {fashion }}=0.528>\beta_{\text {cars }}=0.247 ; \mathrm{t}\right.$-value diff $\left.=-2.67 ; \mathrm{p}=0.01\right)$. Similarly, the relationship between extension attitude (EAT) and perceived value appears to be stronger for fashion shoes than for cars, although differences only emerged at a $90 \%$ confidence interval $\left(\beta_{\text {fashion }}=0.594>\beta_{\text {cars }}\right.$ $=0.267$; $\mathrm{t}$-value diff $=-1.80 ; \mathrm{p}=0.1$. These results indicate that in product categories like fashion shoes, the attitude toward the brand is the most important factor in shaping a positive, general evaluation of a downscale vertical extension. A positive, general evaluation of a downscale vertical extension then seems to affect the perceived value of such extension, whereas the attitude towards the brand does not directly relate to the perceived value of the extension (H3 is not supported for fashion shoes). 
Table 4 - Results of the multi-group analysis

\begin{tabular}{|c|c|c|c|c|c|c|c|c|c|c|}
\hline & & \multicolumn{3}{|c|}{ Brand Characteristics } & \multicolumn{3}{|c|}{ Product Category } & \multicolumn{3}{|c|}{ Price } \\
\hline & & $\begin{array}{l}\text { Premium } \\
\beta(t)\end{array}$ & $\begin{array}{c}\text { Luxury } \\
\beta(t)\end{array}$ & $\begin{array}{l}\text { t-test } \\
\text { diff }\end{array}$ & $\begin{array}{c}\text { Cars } \\
\beta(t) \\
\end{array}$ & $\begin{array}{c}\text { Fashion } \\
\beta(t)\end{array}$ & $\begin{array}{l}\text { t-test } \\
\text { diff }\end{array}$ & $\begin{array}{c}-25 \% \\
\beta(t) \\
\end{array}$ & $\begin{array}{c}-50 \% \\
\beta(t) \\
\end{array}$ & $\begin{array}{l}\text {-test } \\
\text { diff } \\
\end{array}$ \\
\hline H1 & $\mathrm{BAT} \rightarrow \mathrm{EAT}$ & $0.392 *$ & $0.357^{*}$ & 0.31 & $0.247^{*}$ & $0.528 *$ & $-2.67 *$ & $0.403 *$ & $0.271^{*}$ & 1.08 \\
\hline $\mathrm{H} 2$ & $\mathrm{FIT} \rightarrow \mathrm{EAT}$ & $0.307^{*}$ & $0.549^{*}$ & -1.84 & $0.622 *$ & $0.323 *$ & $2.74 *$ & $0.546^{*}$ & $0.413^{*}$ & 1.02 \\
\hline H3 & $\mathrm{BAT} \rightarrow \mathrm{VAL}$ & 0.132 & 0.158 & -0.22 & $0.206 *$ & 0.124 & 0.61 & 0.124 & 0.108 & 0.13 \\
\hline $\mathrm{H} 4$ & $\mathrm{FIT} \rightarrow \mathrm{VAL}$ & 0.211 & 0.047 & 1.07 & $0.332 *$ & -0.027 & $2.38 *$ & 0.098 & 0.090 & 0.06 \\
\hline H5 & $\mathrm{EAT} \rightarrow \mathrm{VAL}$ & $0.375^{*}$ & $0.585^{*}$ & -1.34 & $0.267 *$ & $0.594 *$ & -1.80 & $0.611^{*}$ & $0.428 *$ & 1.17 \\
\hline H6 & $\mathrm{EAT} \rightarrow \mathrm{INT}$ & $0.397^{*}$ & $0.318^{*}$ & 0.61 & $0.378 *$ & $0.289 *$ & 0.68 & $0.390 *$ & $0.302 *$ & 0.68 \\
\hline H7 & $\mathrm{VAL} \rightarrow \mathrm{INT}$ & $0.441^{*}$ & $0.558 *$ & -0.90 & $0.443^{*}$ & $0.571^{*}$ & -1.01 & $0.490 *$ & $0.504 *$ & -0.12 \\
\hline
\end{tabular}

*significant at $\mathrm{p} \leq 0.05$ 


\section{Discussion}

This study has examined the role of perceived value in the relationship between brand attitude, perceived fit, extension attitude and consumers’ purchase intention of downscale vertical extensions of luxury and of premium brands in two product categories: cars and fashion shoes. No earlier study had undertaken such a comprehensive empirical analysis.

This research makes two main contributions to the brand extension literature. First, the luxury brand extension literature is advanced by establishing the role of perceived extension value as a mediator between brand attitude, perceived fit and consumers' evaluations of downscale vertical extensions on consumers' intentions to purchase such extensions. Second, by considering a number of previously disregarded but important variables (brand type, product category and price) the study provides a better understanding of the contextual factors affecting consumers' evaluations of vertical extensions.

The results are discussed below, first for the overall model and then taking into explicit consideration the characteristics of the parent brand, the product category and the price of the downscale extension.

\section{The role of perceived extension value}

Consistent with our hypotheses, we have found that the perceived value of downscale vertical extensions is positively related to the attitude towards the brand and to the attitude towards the extension. In the overall estimation of the conceptual model, perceptions of fit with the parent brand have not been found to be directly associated with the perceived value of the extension, but only indirectly via the extension attitude. Consumers do not seem to consider the perceived fit as an antecedent of the value of the new product and what really determines the perceived value is the general attitude toward both the brand and the extension. While this general result may not hold true in all contexts and for all product categories (see next section), results show that a positive extension attitude may subsume the 
potential effect of fit on the perceived value of the extension and may help to avoid a lower priced extension being considered as ill-fitting with the price/quality and price/status characteristic of luxury brand positioning.

In turn, extension attitude has both a direct and indirect association, through extension value, with consumers' likelihood to purchase the vertical step-down extension of a luxury or premium brand.

In line with our research objectives, a major contribution of this study is to have established the important role of perceived extension value as a mediator of the paths of brand attitude and extension attitude to purchase intention. In addition, we have found that perceived extension value has a greater weight than extension attitude for determining consumers’ purchase intention of vertical extensions of premium and luxury brands. This finding corroborates and extends the suggestion by Lei et al. (2008a: 277) in the context of vertical service line extensions, that: 'compared to extension evaluation that is usually measured in previous studies, perceived value is a more comprehensive and accurate predictor for consumers' behavioural intentions toward extensions.'

Finally, in the context of vertical extensions, the positive relationship between brand attitude and the attitude towards its vertical downscale extension merits explicit consideration (see also discussion at the product category level in the next section).

Even if the brand extension concept (BEC) results lower than the parent brand concept (PBC), as in our downscale vertical extension manipulation here, associations of favourability, liking and appeal towards the parent brand appear to retain a positive effect both directly and indirectly, via the extension evaluation, on the perceived extension value.

These findings provide empirical evidence supporting Desay and Hoyer’s (1993) and Michel and Salha's (2005) theoretical discussions of dominant concept theory as the basis for explaining consumers' mental processes when evaluating horizontal and vertical extensions. 
According to dominant concept theory, core brand associations are independent of context and therefore always transfer to the extension and improve its evaluation. The more central the associations, the greater is their transference to the extension product and the greater is the reinforcement of linkages between such associations and the extensions (Tafani et al., 2009). Whenever there is a possible conflict between the core brand associations and the characteristics of the extension (e.g. the exclusivity of an expensive luxury brand versus the affordability of its downscale vertical extension), then the transfer of core brand associations becomes even more important in avoiding the rejection of the new extended product as inconsistent with the core brand (Desay \& Hoyer, 1993).

The discussion in the next section further elucidates these effects.

\section{Brand characteristics, product category and price}

Desay and Hoyer (1993) postulate that a number of individually related and product related factors could affect the transference or 'matching' of the core brand associations to the extension context. Some intriguing findings have emerged from the more exploratory part of the research, which investigated the effect of the brand characteristics, the product category and the extension price on the process determining the transfer of associations between the parent brand, the perceived value of its extension and purchase intentions.

Overall, our results suggest that the process of evaluation of vertical extensions is similar for luxury and for premium brands and for different price levels. The results of the multi-group analysis for brand type gave some support to the expected stronger association of fit with extension attitude, of extension attitude with perceived extension value and of the latter with purchase intention for luxury than for premium brands, but the differences were not statistically significant. Similarly, multi-sample analysis failed to unveil any statistical difference across the price conditions, either in terms of the direction or of the strength of the relationship between the variables. It should be noted that, contrary to results for the overall 
model, the association of brand attitude with perceived value was not supported in the multigroup analysis relative to the brand or price conditions. This may due to the fact that weak effects are harder to detect in small samples, thus further research is needed.

In contrast, the characteristics of the product category do have a significant effect on how perceptions of vertical extensions of luxury and of premium brands are formed. Perceived fit resulted as more important in shaping extension attitudes and perceived extension value for car brands than for fashion brands. This provides some evidence of the greater difficulty in downscale extensions of luxury and premium brands in product categories where product ranges are narrow in scope and extensions are conspicuous to evaluation by peers. On the other hand, the association of brand attitude with extension attitude and of the latter with perceived extension value was greater for fashion than for cars. What seems to be important for the acceptance and evaluation of downscale extensions of luxury and premium fashion brands are consumers’ overall brand perceptions of favourability, liking and appeal. These results suggest that for product categories like fashion where the range of products on offer is wider and more varied in terms of price ranges, downscale extensions are more acceptable than the equivalent downscale extensions of brands with narrow ranges, such as car brands. In contrast, for car brands, downscale extensions can be problematic in terms of fit perceptions.

Overall, results concerning the effect of the product category characteristics on the process upon which vertical extensions are evaluated are consistent with Desai and Hoyer's (1993) proposition that the degree of differentiation within a product category has an impact on the acceptance of an extension. The easier it is to see the differentiating features among products within a category, e.g. different type ranges of cars, the more difficult it may be to see the fit between the parent brand concept and a line extension. Hence fit assumes a greater role for cars than for fashion brands. 
An additional aspect not directly considered here, but which may help to explain the enhanced role of fit in the process by which evaluations of vertical extensions of luxury and premium car brands are formed, is social risk. DelVecchio and Smith (2005) had suggested that social risk increases the extent to which the product is one that is visibly branded. The greater conspicuousness of luxury and premium car brands to peer evaluation compared to luxury and premium fashion (shoes) brands entails greater social risk attached to a downscale vertical extension of a car brand, hence fit becomes more important.

\section{Implications for practice}

From a practical perspective, at the beginning of the paper we remarked that in order to maintain sales in times of economic uncertainty, luxury and premium brands often resort to downscale vertical extensions strategies (Bokaie, 2008). This study has highlighted a number of important issues for brand managers to consider when vertically extending their luxury and premium brands downwards.

Overall there was no evidence from this analysis of a floor effect for premium brands when compared with luxury brands, rather the main practical implication here is for luxury and premium car brand managers to proceed with care when it comes to extending these brands downwards, since fit with the core brand values needs to be maintained for the extension to be evaluated positively.

Firstly, it is very important not only to build and sustain positive brand attitudes, but these should be made salient also in the extension context, to ensure the success of the extension and enhance its perceived value in the eyes of the consumers. Secondly, a very important finding of this research is the effect of the product category characteristics. Managers should be aware of these differences and should not assume that the same effects are going to occur, and to the same extent, in every product category. For instance, in product categories like cars, consumers may negatively react to luxury and premium brands being 
obviously cheaper and more affordable than the usual range. In these circumstances, it may be actually better to differentiate the downscale extension more; Mercedes’ vertical extension into Class A cars is an example of this kind of strategy.

\section{Limitations and future research directions}

More research is needed with regards to the complex effects of the brand and product category characteristics. First, this study should be replicated and extended to different brands, at different levels on the price/ premium spectrum and in product categories likely to vary in conspicuousness and in the relating social risk. A number of different brands within the same product category could also be compared in order to bring out any market share effects. There is extensive evidence that brand attitudes are strongly correlated with the size or market share of the brand (e.g. Barwise \& Ehrenberg, 1985; Castleberry \& Ehrenberg, 1990; Ehrenberg, Goodhardt, \& Barwise, 1990; Romaniuk \& Sharp, 2000). Since brand attitude has been confirmed as a dominant factor in shaping the evaluation of downscale vertical extensions, the consideration of market share effects seems a logical development of research in this area.

Furthermore, price differentials of different magnitude should be considered, in order to establish any thresholds effects on the evaluation of downscale vertical extensions of brands at different levels in the price/ prestige spectrum.

A limitation of this study is that we have not considered potentially relevant consumer characteristics, such as attitudes towards luxury, ownership effects (as considered by Kirmani et al., 1999) and the representativeness of our sample in terms of the demographic and income profile of luxury or premium brands buyers (especially of cars). Our sample comprised consumers of higher income compared with the general UK population, but their attitudes and behaviours towards vertical brand extensions may differ from those of "real” luxury shoppers. While this is a limitation of our research, higher income consumers may nonetheless be 
important particularly with regards to their perceived value of the downscale vertical extensions of premium brands and purchase intentions. Further research should investigate these issues and delve into how the evaluation of vertical extensions differs among consumers of luxury and non-luxury brands.

Finally, while this research has uncovered a number of important empirical findings in relation to consumers' evaluations of downscale vertical extensions of luxury and of premium brands, further research should also focus on the feedback effects of such extension on the core brands’ image. 


\section{References}

Aaker, D. (1997). Should you take your brand to where the action is? Harvard Business Review, 75 (September-October), 135-143.

Aaker, D., \& Keller, K.L. (1990). Consumer evaluations of brand extensions. Journal of Marketing, 54 (January), 27-41, http://dx.doi.org/10.2307/1252171

Aaker, D.A., \& Joachimsthaler (2000). The Brand Relationship Spectrum: The Key to the Brand Architecture Challenge. California Management Review, 42 (4): 8-23, http://dx.doi.org/10.2307/41166051.

Albrecht, C.-M., Backhaus, C., Gurzki, H., \& Woisetschläger, D.M. (2013). Drivers of Brand Extension Success: What Really Matters for Luxury Brands. Psychology and Marketing, 30 (8), 647-659, http://dx.doi.org/10.1002/mar.20635.

Ambler, T., \& Styles, C. (1997). Brand development versus new product development: toward a process model of extension decisions. Journal of Product and Brand Management, 6 (4), 222-234, http://dx.doi.org/10.1108/10610429710186752.

Barwise, P T., \& Ehrenberg, A. (1985). Consumer Beliefs and Brand Usage. Journal of the Market Research Society, 27 (2), 81-93.

Batra, R., Lenk, P., \& Wedel, M. (2010). Brand Extension Strategy Planning: Empirical Estimation of Brand-Category Personality Fit and Atypicality. Journal of Marketing Research, 17 (April), 335-347, http://dx.doi.org/10.1509/jmkr.47.2.335.

Bearden, W. O., \& Etzel, M. J. (1982). Reference group influence on product and brand purchase decisions. Journal of Consumer Research, 9 (2), 183-194, http://dx.doi.org/10.1086/208911.

Berger, J., \& Heath, C. (2007). Where Consumers Diverge from Others: Identity Signaling and Product Domains. Journal of Consumer Research, 34 (August), 121-134, http://dx.doi.org/10.1086/519142.

Bhat, S., \& Reddy S.K. (2001). The impact of parent brand attribute associations and affect on brand extension evaluation. Journal of Business Research, 53 (3), 111-22, http://dx.doi.org/10.1016/S0148-2963(99)00115-0.

Boisvert, J. (2012). The Impact of Vertical Service Line Extensions and Brand Salience on Reciprocal Transfer of Image and Performance Associations. Journal of Service Research, 15(4), 443-459, http://dx.doi.org/10.1177/1094670512442797.

Bokaie, J. (2008). Profit at the expense of prestige. Marketing, 7 May, 18.

Bourne, F.S. (1957). Group influences in marketing and public relations. In R. Likert, \& S.P. Hayes (Eds.), Some applications of behavioral research. Basel, Switzerland: UNESCO.

Boush, D.M., \& Loken B. (1991). A process-tracing study of brand extension evaluation. Journal of Marketing Research, 28 (February), 16-28, http://dx.doi.org/10.2307/3172723.

Broniarczyk, S. M., \& Alba, J. W. (1994). The importance of the brand in brand extension. Journal of Marketing Research, 31 (May), 214-228, http://dx.doi.org/10.2307/3152195.

Buss, D. (2013). Cadillac, Porsche Emphasize Accessible Luxury as They Lead Industry Sales Surge. Brandchannel. http://www.brandchannel.com/home/post/2013/09/03/Cadillac-Porsche-Accessibility090313.aspx (accessed 11 September 2013).

Castleberry, S. B., \& Ehrenberg, A. S. C. (1990). Brand Usage: A Factor in Consumer Beliefs. Marketing Research, 2 (June), 14-21.

Chin, W. W. (1998). The partial least squares approach for structural equation modeling. In G.A. Marcoulides (ed.) Modern methods for Business Research (pp. 295-336): New Jersey: Lawrence Erlbaum.

Czellar, S. (2003). Consumer attitude toward brand extensions: an integrative model and research propositions. International Journal of Research in Marketing, 20 (1), 97-115, 
http://dx.doi.org/10.1016/S0167-8116(02)00124-6.

Davis, F. D., \& Venkatesh, V. (1996). A critical assessment of potential measurement biases in the technology acceptance model: Three experiments. International Journal of Human and Computer Studies, 45, 19-45, http://dx.doi.org/10.1006/ijhc.1996.0040.

DelVecchio, D., \& Smith, D. C. (2005). Brand extensions price-premiums: the effects of perceived fit and extension product category risk. Journal of the Academy of Marketing Science, 33 (2), 184-196, http://dx.doi.org/10.1177/0092070304269753.

De Barnier, V., Falcy, S., \& Valette-Florence, P. (2012). Do consumers perceive three levels of luxury? A comparison of accessible, intermediate and inaccessible luxury brands.

Journal of Brand Management, 19 (7), 623-636, http://dx.doi.org/10.1057/bm.2012.11.

de Ruyter, K., \& Wetzels, M. (2000). The role of corporate image and extension similarity in service brand extensions. Journal of Economic Psychology, 21, 639-659, http://dx.doi.org/10.1016/S0167-4870(00)00024-6.

Desai, K.K., \& Hoyer, W.D. (1993). Line extensions: a categorization and an information processing perspective. Advances in Consumer Research, 20, 599-606.

Ehrenberg, A., Goodhardt, G., \& Barwise, P. T. (1990). Double Jeopardy Revisited. Journal of Marketing, 54 (3), 82-91, http://dx.doi.org/10.2307/1251818.

Erickson, G.M., \& Johansson, J.K. (1985). The role of price in multi-attribute product evaluations. Journal of Consumer Research, 12 (September), 195-99, http://dx.doi.org/10.1086/208508.

Fornell, C., \& Larcker, D. (1981). Evaluating Structural Equation Models with Unobservable Variable and Measurement Error. Journal of Marketing Research, 18(1): 39-50, http://dx.doi.org/10.2307/3151312.

Gentry, J.W., Putrevu, S., Shultz, C., \& Connuri, S. (2001). How Now Ralph Lauren? The Separation of Brand and Product in a Counterfeit Culture. Advances in Consumer Research, (28), 258-265.

Gierl, H., \& Huettl, V. (2011). A closer look at similarity: The effects of perceived similarity and conjunctive cues on brand extension evaluation. International Journal of Research in Marketing, 28 (2), 120-133, http://dx.doi.org/10.1016/j.ijresmar.2011.01.004.

Grewal, D., Monroe, K.B., \& Krishnan, R. (1998). The effects of price-comparisons advertising on buyers' perceptions of acquisition value, transaction value, and behavioral intentions. Journal of Marketing, 62(April), 46-59, http://dx.doi.org/10.2307/1252160.

Grime, I., Diamantopoulos, A., \& Smith, G. (2002). Consumer evaluations of extensions and their effects on the core brand: key issues and research propositions. European Journal of Marketing, 36 (11/12), 1415-1438, http://dx.doi.org/10.1108/03090560210445245.

Hair, J.F., Black, W.C., Babin, B.J., \& Anderson, R.E. (2010). Multivariate Data Analysis. (7th ed.). Upper Saddle River, NJ: Prentice-Hall.

Hair, J., Hult, G., Ringle, C., \& Sarstedt, M. (2014). A Primer on Partial Least Squares Structural Equation Modeling (PLS-SEM), Sage Publications, Inc. (ISBN: 9781452217444).

Hamilton, R., \& Chernev, A. (2010). The Impact of Product Line Extensions and Consumer Goals on the Formation of Price Image. Journal of Marketing Research, 47 (February), 51-62, http://dx.doi.org/10.1509/jmkr.47.1.51.

Hansen, H., \& Hem, L.E. (2004). Brand extension evaluations: effects of affective commitment, involvement, price consciousness and preference for bundling in the extension category. Advances in Consumer Research, 31 (1), 375-391.

Heath, T. H., DelVecchio, D., \& McCarthy, M.S. (2011). The Asymmetric Effects of Extending Brands to Lower and Higher Quality. Journal of Marketing, 75 (July), 3-20, http://dx.doi.org/10.1509/jmkg.75.4.3. 
Hennings, N., Wiedmann, K.P., Behrens, S., Klarmann, C., \& Carduck, J. (2013). Brand Extensions. A successful strategy in luxury fashion branding? Assessing consumers' implicit associations. Journal of Fashion Marketing and Management, 17 (4), 390-402. http://dx.doi.org/10.1108/JFMM-03-2013-0022

Henseler, J., Ringle, C. M., \& Sinkovics, R. R. (2009). The use of partial least squares path modeling in international marketing. Advances in international marketing, 20, 277-319.

Hulland, J. (1999). Use of partial least squares (PLS) in strategic management research: a review of four recent studies. Strategic Management Journal, 20 (2), 195-204, http://dx.doi.org/10.1002/(SICI)1097-0266(199902)20:2\%3C195::AIDSMJ13\%3E3.3.CO;2-Z.

John, R.D., Loken, B., \& Joiner, C. (1998). The negative impact of extensions: can flagship products be diluted. Journal of Marketing, 62 (January), 19-32, http://dx.doi.org/10.2307/1251800.

Kapoor, H.,, \& Heslop L.A. (2009). Brand positivity and competitive effects on the evaluation of brand extensions. International Journal of Research in Marketing, 26 (3), 228-237, http://dx.doi.org/10.1016/j.ijresmar.2009.05.001.

Keller, K.L., \& Aaker, D. (1992). The effects of sequential introduction of brand extensions. Journal of Marketing Research, 29 (February), 35-50, http://dx.doi.org/10.2307/3172491.

Keller, K. L., \& Aaker, D. (1997). Managing the corporate brand: The effect of corporate marketing activity on consumer evaluations of brand extensions. Working Paper Report No. 97-106, May. Cambridge, MA: Marketing Science Institute.

Kim, C.K., \& Lavack, A.M. (1996). Vertical brand extensions: current research and managerial implications. Journal of Product and Brand Management, 5 (6), 24-37, http://dx.doi.org/10.1108/10610429610152813.

Kim, C.K., Lavack A.M., \& Smith, M. (2001). Consumer evaluation of vertical brand extensions and core brands. Journal of Business Research, 52 (3), 211-222, http://dx.doi.org/10.1016/S0148-2963(99)00107-1.

Kirmani, A., Sood, S., \& Bridges, S. (1999). The ownership effect in consumer responses to brand line stretches. Journal of Marketing, 63 (January), 88-101, http://dx.doi.org/10.2307/1252003.

Kleijnen, M., de Ruyter, K., \& Werzels, M. (2007). An assessment of value creation in mobile service delivery and the moderating role of time consciousness. Journal of Retailing, 83 (1), 33-46, http://dx.doi.org/10.1016/j.jretai.2006.10.004.

Klink, R. R., \& Smith, D. C. (2001). Threats to the external validity of brand extension research. Journal of Marketing Research, 38 (August), 326-335, http://dx.doi.org/10.1509/jmkr.38.3.326.18864.

Lafferty, B.A. (2007). The relevance of fit in a cause - brand alliance when consumers evaluate corporate credibility. Journal of Business Research, 60 (5), 447-453, http://dx.doi.org/10.1016/j.jbusres.2006.09.030.

Leavitt, H.J. (1954). A note on some experimental findings about the meanings of price. Journal of Business, 27 (3), 205-10, http://dx.doi.org/10.1086/294039.

Lei, J., de Ruyter, K., \& Wetzels, M. (2008a). Consumer responses to vertical service line extensions. Journal of Retailing, 84 (3), 268-280, http://dx.doi.org/10.1016/j.jretai.2008.05.001.

Lei, J., Dawar, N., \& Lemmink, J. (2008b). Negative spillover in brand portfolios: exploring the antecedents of asymmetric effects. Journal of Marketing, 72 (May), 111-123, http://dx.doi.org/10.1509/jmkg.72.3.111.

Les Échos (2004). Étendre sa marque, un pari souvent gagnat N`19301, 7 December, page 15. http://archives.lesechos.fr/archives/2004/LesEchos/19301-50-ECH.htm (accessed 04 
August 2008).

Liu, C. M. (2002). The effects of promotional activities on brand decision in the cellular telephone industry. Journal of Product and Brand Management, 11 (1), 42-51, http://dx.doi.org/10.1108/10610420210419540.

Liu, S. C., \& Choi, T. M. (2009). Consumer attitudes towards brand extensions of designerlabels and mass-market labels in Hong Kong. Journal of Fashion Marketing and Management, 13 (4), 527-540, http://dx.doi.org/10.1108/13612020910991385.

Loken B., \& John, R. D. (1993). Diluting brand beliefs: when do brand extensions have a negative impact? Journal of Marketing, 57 (July), 71-84, http://dx.doi.org/10.2307/1251855.

Magnoni, F., \& Roux, E. (2012). The impact of step-down line extension on consumer-brand relationships: A risky strategy for luxury brands. Journal of Brand Management, 19 (7), 595-608, http://dx.doi.org/10.1057/bm.2012.8.

Martin, I.M., \& Stewart, D.W. (2001). The differential impact of goal congruency on attitudes, intentions, and the transfer of brand equity. Journal of Marketing Research, XXXVIII (November), 471-484, http://dx.doi.org/10.1509/jmkr.38.4.471.18912.

Martinez, E., \& Pina, J.M. (2003). The negative impact of brand extensions on parent brand image. Journal of Product and Brand Management, 12 (6/7), 432-448, http://dx.doi.org/10.1108/10610420310506001.

Matthiesen, I.M., \& Phau, I. (2010). Brand image inconsistencies of luxury fashion brands. A buyer-seller exchange situation model of Hugo Boss Australia. Journal of Fashion Marketing and Management, 14 (2), 202-218, http://dx.doi.org/10.1108/13612021011046066.

Michel, G., \& Salha, B. (2005). L'extension de gamme verticale: clarification du concept. Recherche et Applications en Marketing, 20 (1), 65-78 (in French), http://dx.doi.org/10.1177/076737010502000104.

Milberg, S.J., Park, C.W., \& McCarthy, M.S. (1997). Managing negative feedback effects associated with brand extensions: the impact of alternative branding strategies. Journal of Consumer Psychology, 6 (2), 119-140, http://dx.doi.org/10.1207/s15327663jcp0602_01.

Mishra, S., Umesh, U.N., \& Stem, D.E. Jr. (1993). Antecedents of the attraction effect: an information-processing approach. Journal of Marketing Research, 30 (3), 331-349, http://dx.doi.org/10.2307/3172885.

Munthree, S., Bick, G. R., \& Abratt, R. (2006). A framework for brand revitalization through an upscale line extension. Journal of Product and Brand Management, 15 (3), 157-167, http://dx.doi.org/10.1108/10610420610668595.

Musante, M. (2007). Brand portfolio influences on vertical brand extension evaluations. Innovative Marketing, 3 (4), 59-65.

Nia, A., \& Zaichkowsky, J.L. (2000). Do counterfeits devalue the ownership of luxury brands? Journal of Product \& Brand Management, 9 (7), 485-497, http://dx.doi.org/10.1108/10610420010351402.

Niedrich, R.W., Sharma, S., \& Wedell, D.H. (2001). Reference price and price perceptions: a comparison of alternative models. Journal of Consumer Research, 28 (December), 339354, http://dx.doi.org/10.1086/323726.

Niedrich, R.W., Weathers, D., Hill, R.C., \& Bell, D.R. (2009). Specifying price judgments with range-frequency theory in models of brand choice. Journal of Marketing Research, 46 (October), 693-702, http://dx.doi.org/10.1509/jmkr.46.5.693.

Nueno J.L. \& Quelch J. (1998). The mass marketing of luxury. Business Horizons, 41 (6), 6169, http://dx.doi.org/10.1016/S0007-6813(98)90023-4. 
O’Cass, A., \& Grace, D. (2004). Exploring consumer experiences with a service brand. Journal of Product and Brand Management, 13 (4), 257-268, http://dx.doi.org/10.1108/10610420410546961.

Office of National Statistics (2014). Annual Mid-Year Population Estimates for the UK, Office for National Statistics, http://www.statistics.gov.uk/hub/index.html, retrieved 9 September, 2014.

Park, C. W., Milberg, S., \& Lawson, R. (1991). Evaluations of brand extensions: the role of product feature similarity and brand concept consistency. Journal of Consumer Research, 18 (September), 185-193, http://dx.doi.org/10.1086/209251.

Randall T., Ulrich K., \& Reibstein D. (1998). Brand equity and vertical product line extent. Marketing Science, 17 (4), 356-379, http://dx.doi.org/10.1287/mksc.17.4.356.

Rao, A.R., \& Monroe, K.B. (1988). The moderating effect of prior knowledge on cue utilization in product evaluations. Journal of Consumer Research, 15 (September), 253264, http://dx.doi.org/10.1086/209162.

Reddy, M., Terblanche, N., Pitt, L., \& Parent, M. (2009). How far can luxury brands travel? Avoiding the pitfalls of luxury brand extension. Business Horizons, 52, 187-197, http://dx.doi.org/10.1016/j.bushor.2008.11.001.

Reddy, S.K., Holak S.L., \& Bhat S. (1994). To extend or not to extend: success determinants of line extensions. Journal of Marketing Research, 31 (May), 243-262, http://dx.doi.org/10.2307/3152197.

Ringle, C.M., Wende, S., \& Will, A. (2005). SmartPLS 2.0 (M3) beta. Hamburg: http://www.smartpls.de

Rohrer, F. (2009). "UK | Magazine | Just what is a big salary?". BBC News. Retrieved 10 December, 2013.

Romaniuk, J., \& Sharp, B. (2000). Using Known Patterns of Image Data to Determine Brand Positioning. International Journal of Market Research, 42 (2), 219-230.

Sattler, H., Völckner, F., Riediger, C., \& Ringle, C.M. (2010). The impact of brand extensions success drivers on brand extensions price premiums. International Journal of Research in Marketing, 27 (4), 319-328, http://dx.doi.org/10.1016/j.ijresmar.2010.08.005.

Sheinin, D. A., \& Schmitt, B. H. (1994). Extending brands with new product concepts: the role of category attribute congruity, brand affect, and brand breadth. Journal of Business Research, 31 (1), 1-10, http://dx.doi.org/10.1016/0148-2963(94)90040-X.

Speed, R. (1998). Choosing between line extensions and second brands: the case of the Australian and New Zealand wine industries. Journal of Product and Brand Management, 7 (6), 519-536, http://dx.doi.org/10.1108/10610429810244684.

Sweeney, J.C., \& Soutar, G.N. (2001). Consumer Perceived Value: the Development of a Multiple Item Scale. Journal of Retailing, 77 (2): 203-220, http://dx.doi.org/10.1016/S0022-4359(01)00041-0.

Tafani, E., Michel, G., \& Rosa, E. (2009). Vertical Product Line Extension Strategies: an Evaluation of Brand Halo Effect according to Range Level. Recherche et Applications en Marketing, 24 (2), 73-88, http://dx.doi.org/10.1177/205157070902400204.

Taylor, V.A., \& Bearden, W.O. (2002). The effects of price on brand extension evaluations: the moderating role of extension similarity. Journal of the Academy of Marketing Science, 30 (2), 131-140, http://dx.doi.org/10.1177/03079459994380.

Tenenhaus, V.E., Vinzi, Y-M., \& Chatelin, C.L. (2005). PLS Path Modeling. Computational Statistics \& Data Analysis, 48 (1), 159-205, http://dx.doi.org/10.1016/j.csda.2004.03.005.

Till, B. D., \& Priluck, R. L. (2000). Stimulus generalization in classical conditioning: an initial investigation and extension. Psychology and Marketing, 17 (1-January), 55-64, http://dx.doi.org/10.1002/(SICI)1520-6793(200001)17:1\%3C55::AID- 
MAR4\%3E3.3.CO;2-3.

Truong Y., McColl, R., \& Kitchen, P.J. (2009). New luxury brand positioning and the emergence of masstige brands. Journal of Brand Management, 16 (5/6), 375-382, http://dx.doi.org/10.1057/bm.2009.1.

Truong, Y., Simmons, G., McColl, R., \& Kitchen, P. J. (2008). Status and conspicuousness are they related? Strategic marketing implications for luxury brands. Journal of Strategic Marketing, 16 (3), 189-203, http://dx.doi.org/10.1080/09652540802117124.

Vigneron, F. \& Johnson, L. W. (2004). Measuring perceptions of brand luxury. Journal of Brand Management, 11 (6), 484-506, http://dx.doi.org/10.1057/palgrave.bm.2540194.

Völckner, F., \& Sattler, H. (2006). Drivers of brand extension success. Journal of Marketing, 70 (2), 18-34, http://dx.doi.org/10.1509/jmkg.70.2.18.

Völckner, F., Sattler, H., Hennig-Thurau, T. \& Ringle, C.M. (2010). The Role of Parent Brand Quality for Service Brand Extension Success. Journal of Services Research, 13 (4), 379-396, http://dx.doi.org/10.1177/1094670510370054.

Wetzels, M., Odekerken-Schröder, G., \& van Oppen, C. (2009). Using PLS path modeling for assessing hierarchical construct models: guidelines and empirical illustration. MIS Quarterly, 33 (1), 177-195.

Zeithaml V.A. (1988). Consumer Perceptions of Price, Quality and Value: A Means-End Model and Synthesis of Evidence. Journal of Marketing, 52 (3), 2-21, http://dx.doi.org/10.2307/1251446. 
Appendix - Descriptive results and normality tests (Cars)

\begin{tabular}{|c|c|c|c|c|c|c|c|c|c|c|c|c|c|c|c|c|}
\hline \multirow[b]{2}{*}{ Items } & \multicolumn{4}{|c|}{ PORSCHE -25\% (n=30) } & \multicolumn{4}{|c|}{ PORSCHE -50\% $(n=28)$} & \multicolumn{4}{|c|}{$A U D I-25 \%(n=28)$} & \multicolumn{4}{|c|}{ AUDI $-50 \%(n=30)$} \\
\hline & $M$ & $S D$ & $\begin{array}{c}\text { Skewness } \\
\text { Test /Z/ }\end{array}$ & $\begin{array}{c}\text { Kurtosis } \\
\text { Test /Z/ }\end{array}$ & $M$ & $S D$ & $\begin{array}{c}\text { Skewness } \\
\text { Test /Z/ }\end{array}$ & $\begin{array}{c}\text { Kurtosis } \\
\text { Test /Z/ }\end{array}$ & $M$ & $S D$ & $\begin{array}{c}\text { Skewness } \\
\text { Test /Z/ }\end{array}$ & $\begin{array}{c}\text { Kurtosis } \\
\text { Test /Z/ }\end{array}$ & $M$ & $S D$ & $\begin{array}{c}\text { Skewness } \\
\text { Test /Z/ }\end{array}$ & $\begin{array}{c}\text { Kurtosis } \\
\text { Test /Z/ }\end{array}$ \\
\hline EXP1 & 3.90 & 1.81 & 0.461 & 1.133 & 4.43 & 1.67 & 0.070 & 1.100 & 4.18 & 1.59 & 1.317 & 0.922 & 4.07 & 1.41 & -1.583 & 0.898 \\
\hline EXP2 & 4.30 & 1.42 & 0.295 & 0.546 & 4.25 & 1.67 & -0.737 & 0.809 & 4.36 & 1.68 & -0.363 & 1.120 & 4.07 & 1.14 & -1.019 & 0.782 \\
\hline EXP3 & 4.00 & 1.62 & 1.101 & 1.020 & 4.21 & 1.40 & -0.338 & 0.569 & 4.14 & 1.72 & 0.429 & 1.183 & 4.07 & 1.20 & -1.215 & 0.614 \\
\hline FAM & 4.17 & 2.26 & -0.473 & 1.336 & 5.07 & 1.72 & -1.016 & 0.778 & 4.04 & 1.99 & -0.259 & 1.149 & 4.30 & 1.75 & 0.110 & 1.115 \\
\hline PBC1 & 6.40 & 0.97 & $-5.007 *$ & $2.454 *$ & 6.39 & 0.79 & -1.930 & 0.965 & 5.11 & 1.23 & $-2.841^{*}$ & $1.962 *$ & 5.20 & 1.22 & -1.829 & 0.759 \\
\hline PBC2 & 6.07 & 1.44 & $-4.492 *$ & 1.944 & 5.96 & 1.29 & $-5.395^{*}$ & $2.954 *$ & 5.00 & 1.19 & -0.651 & 0.616 & 5.27 & 1.08 & -0.937 & 0.650 \\
\hline BAT1 & 4.63 & 1.67 & -0.972 & 0.882 & 5.57 & 1.26 & -1.206 & 0.892 & 5.07 & 1.54 & -1.186 & 0.937 & 5.50 & 1.01 & 0.253 & 1.099 \\
\hline BAT2 & 4.43 & 1.76 & -0.731 & 0.887 & 5.25 & 1.24 & -0.018 & 1.271 & 5.29 & 1.18 & -0.383 & 0.888 & 5.47 & 1.14 & 0.382 & 1.282 \\
\hline BAT3 & 4.60 & 2.06 & -0.831 & 1.161 & 5.25 & 1.30 & -0.642 & 1.099 & 5.32 & 1.12 & -0.052 & 0.963 & 5.37 & 1.07 & 0.660 & 1.147 \\
\hline FIT1 & 3.67 & 1.56 & 0.178 & 0.707 & 3.18 & 1.59 & 1.723 & 0.213 & 4.93 & 1.27 & -0.986 & 0.695 & 5.17 & 1.26 & -1.044 & 0.492 \\
\hline FIT2 & 4.03 & 1.65 & -0.710 & 0.845 & 3.61 & 1.52 & 0.270 & 1.073 & 5.00 & 1.52 & -1.560 & 0.766 & 5.37 & 1.03 & -1.454 & 0.558 \\
\hline FIT3 & 3.73 & 1.48 & 0.520 & 0.325 & 3.71 & 1.49 & 0.546 & 0.371 & 5.36 & 1.10 & -1.376 & 0.457 & 5.23 & 1.10 & -0.009 & 1.039 \\
\hline EAT1 & 4.03 & 1.59 & -0.787 & 0.882 & 3.79 & 1.23 & -0.467 & 0.506 & 5.18 & 0.98 & -0.871 & 0.701 & 5.27 & 1.17 & -1.314 & 0.833 \\
\hline EAT2 & 4.00 & 1.66 & -0.794 & 0.906 & 3.68 & 1.22 & -0.569 & 0.746 & 5.21 & 0.92 & -1.744 & 1.068 & 5.03 & 1.50 & -1.845 & 0.874 \\
\hline EAT3 & 4.03 & 1.63 & -0.133 & 0.819 & 3.82 & 1.36 & -0.286 & 0.763 & 5.07 & 1.18 & -1.315 & 0.490 & 5.00 & 1.62 & -1.714 & 0.247 \\
\hline VAL1 & 4.27 & 1.84 & -0.403 & 0.874 & 4.75 & 1.40 & -0.868 & 0.901 & 5.36 & 0.99 & $-2.390 *$ & 0.829 & 5.73 & 1.31 & $-2.208^{*}$ & 0.444 \\
\hline VAL2 & 4.20 & 1.75 & -0.478 & 0.838 & 4.57 & 1.48 & -1.184 & 0.376 & 5.36 & 1.16 & -1.057 & 0.817 & 5.43 & 1.36 & -1.831 & 0.211 \\
\hline VAL3 & 4.17 & 1.80 & -0.447 & 0.988 & 4.36 & 1.55 & -0.449 & 0.812 & 5.07 & 1.33 & -0.778 & 1.173 & 5.20 & 1.27 & -0.941 & 0.352 \\
\hline BEC1 & 5.10 & 1.24 & $-2.101^{*}$ & 1.189 & 3.79 & 1.29 & 0.977 & 0.202 & 4.54 & 1.17 & -0.379 & 0.559 & 4.27 & 1.53 & -0.117 & 1.006 \\
\hline BEC2 & 5.00 & 1.26 & -1.820 & 0.754 & 4.25 & 1.40 & 0.086 & 0.432 & 4.46 & 1.37 & -0.655 & 0.908 & 4.30 & 1.42 & -1.344 & 0.813 \\
\hline INT1 & 3.87 & 1.68 & -1.899 & 0.889 & 3.82 & 1.59 & 0.172 & 0.870 & 4.79 & 1.55 & -1.612 & 0.407 & 5.00 & 1.37 & -1.431 & 0.466 \\
\hline INT2 & 3.90 & 1.77 & -1.028 & 1.006 & 3.89 & 1.71 & 0.188 & 0.994 & 5.04 & 1.84 & -1.882 & 0.461 & 4.73 & 1.57 & -0.621 & 0.900 \\
\hline INT3 & 3.73 & 1.86 & -0.970 & 1.226 & 3.50 & 1.69 & 0.170 & 0.999 & 4.61 & 1.81 & -1.562 & 0.546 & 4.47 & 1.53 & -0.719 & 0.765 \\
\hline
\end{tabular}

M: media, SD: standard deviation $\quad *=$ significant at $\mathrm{p} \leq 0.05$ (non-normal) 
Appendix - Descriptive results and normality tests (Fashion)

\begin{tabular}{|c|c|c|c|c|c|c|c|c|c|c|c|c|c|c|c|c|}
\hline \multirow[b]{2}{*}{ Items } & \multicolumn{4}{|c|}{ PRADA -25\% $(n=30)$} & \multicolumn{4}{|c|}{ PRADA $-50 \%(n=30)$} & \multicolumn{4}{|c|}{ DIESEL -25\% $(n=30)$} & \multicolumn{4}{|c|}{ DIESEL -50\% $(n=30)$} \\
\hline & $M$ & $S D$ & $\begin{array}{c}\text { Skewness } \\
\text { Test /Z/ }\end{array}$ & $\begin{array}{c}\text { Kurtosis } \\
\text { Test /Z/ }\end{array}$ & $M$ & $S D$ & $\begin{array}{c}\text { Skewness } \\
\text { Test /Z/ }\end{array}$ & $\begin{array}{c}\text { Kurtosis } \\
\text { Test /Z/ }\end{array}$ & $M$ & $S D$ & $\begin{array}{c}\text { Skewness } \\
\text { Test /Z/ }\end{array}$ & $\begin{array}{c}\text { Kurtosis } \\
\text { Test /Z/ }\end{array}$ & $M$ & $S D$ & $\begin{array}{c}\text { Skewness } \\
\text { Test /Z/ }\end{array}$ & $\begin{array}{c}\text { Kurtosis } \\
\text { Test /Z/ }\end{array}$ \\
\hline EXP1 & 4.60 & 1.67 & -1.046 & 0.807 & 4.47 & 1.48 & -0.960 & 1.238 & 4.67 & 1.49 & -1.513 & 0.056 & 5.10 & 1.40 & -0.824 & 0.957 \\
\hline EXP2 & 4.90 & 1.49 & -1.443 & 0.814 & 4.87 & 1.36 & -0.641 & 0.956 & 4.73 & 1.08 & -0.709 & 0.643 & 5.10 & 1.21 & -1.058 & 0.772 \\
\hline EXP3 & 5.13 & 1.61 & -1.531 & 0.226 & 4.90 & 1.12 & -0.241 & 0.813 & 5.43 & 1.07 & -1.039 & 0.476 & 5.30 & 1.26 & -1.179 & 0.846 \\
\hline FAM & 5.70 & 1.26 & -1.653 & 0.787 & 5.43 & 1.19 & -0.671 & 0.864 & 5.00 & 1.49 & -1.584 & 0.910 & 4.83 & 1.46 & -0.435 & 0.865 \\
\hline PBC1 & 6.43 & 0.73 & $-2.113^{*}$ & 0.754 & 6.13 & 0.82 & -0.607 & 1.323 & 4.57 & 1.17 & $-3.031 *$ & 1.617 & 4.93 & 0.91 & 1.714 & 0.386 \\
\hline PBC2 & 6.23 & 0.94 & $-2.448 *$ & 0.518 & 5.77 & 0.97 & -0.516 & 1.048 & 4.53 & 1.48 & -1.607 & 0.624 & 5.00 & 1.29 & -0.732 & 0.463 \\
\hline BAT1 & 5.13 & 1.46 & $-2.262 *$ & 0.612 & 5.63 & 0.96 & -0.951 & 0.776 & 4.93 & 1.41 & $-2.653 *$ & 1.013 & 4.73 & 0.94 & -0.487 & 0.766 \\
\hline BAT2 & 5.43 & 1.25 & -0.284 & 1.246 & 5.50 & 0.86 & 1.220 & 0.768 & 4.97 & 1.03 & -0.777 & 0.739 & 4.93 & 1.20 & 0.019 & 0.976 \\
\hline BAT3 & 5.67 & 1.12 & $-1.962 *$ & 0.679 & 5.53 & 0.97 & -0.235 & 0.556 & 4.90 & 1.12 & -0.970 & 0.902 & 5.03 & 1.13 & -0.523 & 0.431 \\
\hline FIT1 & 4.77 & 1.59 & -0.844 & 1.014 & 4.23 & 1.96 & -0.130 & 1.246 & 4.93 & 1.41 & -0.627 & 0.662 & 5.00 & 1.36 & -1.635 & 0.202 \\
\hline FIT2 & 4.67 & 1.42 & -1.210 & 0.602 & 4.30 & 1.80 & -0.246 & 1.174 & 4.70 & 1.42 & -1.024 & 0.818 & 4.87 & 1.25 & -0.959 & 0.641 \\
\hline FIT3 & 4.80 & 1.35 & -1.623 & 0.342 & 4.27 & 1.84 & -0.235 & 1.211 & 4.80 & 1.45 & -1.177 & 0.710 & 5.00 & 1.26 & -1.040 & 0.401 \\
\hline EAT1 & 5.57 & 1.36 & $-2.745 *$ & 1.287 & 5.57 & 1.04 & -0.907 & 0.410 & 4.83 & 1.23 & -1.417 & 0.685 & 5.10 & 1.24 & -1.286 & 0.162 \\
\hline EAT2 & 5.70 & 1.34 & $-3.113 *$ & 1.574 & 5.47 & 1.11 & -0.941 & 0.013 & 5.00 & 1.11 & -0.375 & 0.913 & 5.10 & 1.21 & 0.395 & 1.077 \\
\hline EAT3 & 5.63 & 1.52 & $-3.153 *$ & 1.211 & 5.40 & 1.10 & -0.140 & 0.892 & 5.00 & 1.31 & -1.147 & 1.140 & 5.33 & 1.18 & -0.405 & 0.908 \\
\hline VAL1 & 5.73 & 1.34 & $-2.892 *$ & 1.202 & 6.33 & 0.92 & $-3.065 *$ & 1.038 & 5.03 & 1.38 & -1.144 & 0.978 & 5.57 & 1.22 & $-2.659 *$ & 1.296 \\
\hline VAL2 & 5.77 & 1.52 & $-3.262 *$ & 1.124 & 6.07 & 1.08 & $-1.974 *$ & 0.832 & 5.10 & 1.40 & -1.204 & 0.923 & 5.60 & 1.22 & $-2.296 *$ & 1.113 \\
\hline VAL3 & 5.77 & 1.55 & $-3.090 *$ & 0.993 & 5.97 & 1.13 & -1.281 & 1.200 & 4.80 & 1.47 & -0.926 & 0.880 & 5.43 & 1.25 & -1.611 & 0.528 \\
\hline BEC1 & 5.40 & 0.97 & -1.006 & 0.216 & 5.33 & 0.96 & -1.156 & 0.423 & 4.27 & 1.14 & 0.066 & 0.499 & 4.70 & 0.99 & 1.013 & 0.728 \\
\hline BEC2 & 5.77 & 1.22 & -1.432 & 0.972 & 5.37 & 1.03 & -0.984 & 0.786 & 4.27 & 1.26 & -0.229 & 0.770 & 4.90 & 0.88 & 0.480 & 0.293 \\
\hline INT1 & 4.77 & 1.79 & -1.907 & 0.174 & 5.77 & 1.04 & $-2.051^{*}$ & 0.773 & 4.30 & 1.39 & -1.359 & 0.815 & 4.17 & 1.97 & -1.061 & 1.279 \\
\hline INT2 & 5.50 & 1.83 & $-3.243^{*}$ & 1.158 & 5.80 & 1.00 & -0.042 & 1.264 & 5.00 & 1.68 & -1.201 & 0.810 & 4.50 & 2.08 & -0.894 & 1.226 \\
\hline INT3 & 5.10 & 1.86 & $-2.531^{*}$ & 0.718 & 5.80 & 0.96 & -0.164 & 1.172 & 4.57 & 1.57 & -1.251 & 0.296 & 4.23 & 2.03 & -0.735 & 1.197 \\
\hline
\end{tabular}

M: media, SD: standard deviation $\quad *=$ significant at $\mathrm{p} \leq 0.05$ (non-normal) 